Article

\title{
Efficient Synthesis of Novel 1,3,4-Oxadiazoles Bearing a 4-N,N-Dimethylaminoquinazoline Scaffold via Palladium-Catalyzed Suzuki Cross-Coupling Reactions
}

\author{
Barbara Wołek ${ }^{1}$, Mateusz Werłos ${ }^{1}$, Magdalena Komander ${ }^{1}$ and Agnieszka Kudelko ${ }^{2, *} \mathbb{C}$ \\ 1 Selvita Services Sp. Z o.o., Bobrzyńskiego 14, 30348 Kraków, Poland; barbara.wolek@selvita.com (B.W.); \\ mateusz.werlos@selvita.com (M.W.); magdalena.komander@selvita.com (M.K.) \\ 2 Department of Chemical Organic Technology and Petrochemistry, The Silesian University of Technology, \\ Krzywoustego 4, 44100 Gliwice, Poland \\ * Correspondence: agnieszka.kudelko@polsl.pl; Tel.: +48-32-237-17-29
}

Received: 12 October 2020; Accepted: 2 November 2020; Published: 5 November 2020

\begin{abstract}
Two series of novel (symmetrical and unsymmetrical) quinazolinylphenyl-1,3,4-oxadiazole derivatives were synthesized using palladium-catalyzed Suzuki cross-coupling reactions. The presented synthetic methodology is based on the use of bromine-substituted 2-phenyl-4- $\mathrm{N}, \mathrm{N}$ dimethylaminoquinazolines and either a boronic acid pinacol ester or a diboronic acid bis(pinacol) ester of 2,5-diphenyl-1,3,4-oxadiazole. The reactions are conducted in a two-phase solvent system in the presence of catalytic amounts of [1,1'-bis(diphenylphosphino)ferrocene]-dichloropalladium(II), sodium carbonate, and tetrabutylammonium bromide, which plays the role of a phase-transfer catalyst. The luminescence properties of the obtained compounds are discussed in the context of applying these compounds in optoelectronics. Specifically, two highly-conjugated final products: $\mathrm{N}, \mathrm{N}$-dimethyl-2-phenyl-6-(4-(5-phenyl-1,3,4-oxadiazol-2-yl)phenyl)quinazolin-4-amine (8f) and 6,6'(4,4'-(1,3,4-oxadiazole-2,5-diyl)bis(4,1-phenylene))bis( $N, N$-dimethylquinazolin-4-amine $(9 \mathrm{f})$, which contain a 1,3,4-oxadiazole moiety connected to a quinazoline ring by a 1,4-phenylene linker at the 6 position, exhibit strong fluorescence emission and high quantum yields.
\end{abstract}

Keywords: heterocycles; Suzuki cross-coupling; phase-transfer catalysis; palladium; catalysis

\section{Introduction}

Heterocyclic compounds containing five-membered diazole or six-membered diazine scaffolds have recently attracted attention due to the fact that they participate in a wide range of biological interactions and have potential for various industrial applications. One subgroup of the diazole family includes 1,3,4-oxadiazole and its derivatives. Some of these compounds are well-known and already applied in the medicinal field, as integrase inhibitors to treat HIV (raltegravir) [1,2], hepatitis $\mathrm{B}$ and $\mathrm{C}$ virus (HBV, $\mathrm{HCV}$ ) inhibitors [3,4], anticancer drugs (zibotentan), and as antimicrobial (furamizole) [4,5], antifungal [4,6], and antiallergic agents [7]. Because of their favorable thermal and luminescent properties, compounds based on the 1,3,4-oxadiazole ring are also candidates for optoelectronic materials, including organic light emitting diodes (OLEDs) [8,9], liquid crystals [10], metal ion sensors [11,12], and coordination polymers [13]. The most popular method for synthesizing the 1,3,4-oxadiazole scaffold involves cyclization of $N, N^{\prime}$-diacylhydrazine promoted by $\mathrm{SOCl}_{2}$ [14], $\mathrm{BF}_{3} \cdot \mathrm{Et}_{2} \mathrm{O}$ [15], $\mathrm{TsCl}$ and various bases including 1,8-diazabicyclo [5.4.0]undec-7-ene (DBU), $\mathrm{Et}_{3} \mathrm{~N}$, pyridine [16]. Alternatively, some reports have described (i) oxidative cyclization of $N$-acylhydrazones with different oxidizing agents, such as Dess-Martin periodinane (DMP) [17], N-chlorosuccinimide (NCS) 
and DBU [18], (diacetoxyiodo)benzene [19], $\mathrm{KMnO}_{4}$ [20] or 2,3-dichloro-5,6-dicyano-1,4-benzoquinone (DDQ) [21], (ii) photoisomerization of 1,2,4-oxadiazoles [22], (iii) heterocyclization of semicarbazide, thiosemicarbazide, or selenosemicarbazide derivatives [23,24], or (iv) $\mathrm{N}$-acylation followed by ring opening/closing of tetrazoles [25,26].

Another interesting heterocyclic arrangement is quinazoline, which belongs to the subgroup of 1,3-diazines. Many representatives of this class of compound are applied in medicine as antimalarial [27], antimicrobial and anticancer agents [28-30], or they serve as ligands for benzodiazepine and gamma-aminobutyric acid (GABA) receptors in the central nervous system [31]. Additionally, some are applied in agrochemistry [32], and quinazoline-based nucleosides have been reported as interesting new materials exhibiting nonlinear optical or fluorescent properties, highlighting their potential use in OLEDs [33]. A wide range of synthetic procedures allow generation of the studied quinazoline derivatives, including amidation and oxidative ring closure of 2-aminobenzoic acid derivatives (e.g., 2-aminobenzonitrile [34], 2-aminobenzoic acid [35] and 2-aminobenzamide [36,37]), condensation of imidates with 2-aminobenzoic acid [38], or reacting anthranilate esters with guanidine [39-41]. An additional, recently described methodology involves cyclization of 2-aminobenzophenones and benzylamines in the presence of $t-\mathrm{BuOOH}$ and catalytic amounts of $\mathrm{I}_{2}$ or ceric ammonium nitrate (CAN) [42,43].

The rapidly developing field of material sciences has directed the interest of numerous research groups towards finding new organic arrangements that exhibit interesting luminescent properties. An optimized organic luminophore is typically comprised of an extended $\pi$-conjugated chromophore system embodying suitable electron-hole transporting properties, high external quantum efficiency and brightness, as well as chemical and thermal stability [44-46]. A comprehensive literature survey revealed the possibility of modifying luminophore electron-transporting properties by direct or indirect (via the appropriate linker) conjugation of the target molecule with other electron-deficient systems, such as tetrazines, pyridines, quinolines, quinazolines, furans, thiophenes, selenophenes, or 1,3,4-oxadiazoles. [47-53]. Previous work conducted in our laboratory developed the synthesis of novel organic hybrids containing 1,3,4-oxadiazole, 1,3,4-thiadiazole, or 1,2,4-triazole cores conjugated via phenylene linker to different homo- and heteroaromatic arrangements, which resulted in the generation of products with high fluorescence quantum yields [53]. Building upon these results involving novel conjugated diazole-derived monomers for potential optoelectronic applications, herein we describe the combination of two different individual structural motifs (i.e., 1,3,4-oxadiazole and quinazoline) using a phenylene linker via a palladium-catalyzed Suzuki cross-coupling reaction (Figure 1). It is worth mentioning that Suzuki cross-coupling reactions play an important role in the catalytic construction of C-C bonds, and numerous papers and reviews discussing various catalytic systems, general reaction conditions, and potential applications have been published in recent years [54,55].

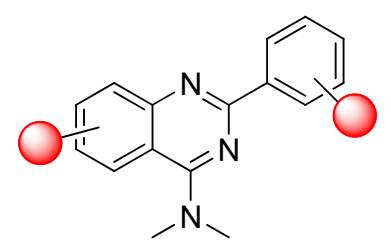

quinazoline scaffold

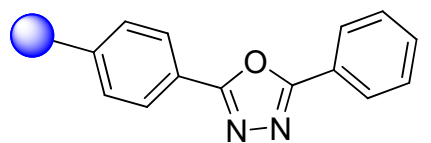

2,5-diphenyl-1,3,4-oxadiazole scaffold

coupling sites

Figure 1. Building scaffolds of the synthesized arrangements with the indicated coupling sites.

\section{Results and Discussion}

Quinazoline precursors 2a-g were prepared in a two-step synthesis according to methodologies described in the literature [56-58]. The starting material was a benzamide derivative $\mathbf{1}$ substituted at 
the ortho, meta, or para position of the $N$-phenyl ring $(X=B r$, Scheme 1$)$, or at the meta or para position of the benzamide ring $(\mathrm{Y}=\mathrm{Cl}, \mathrm{Br}$, Scheme 1). In order to obtain the desired products $\mathbf{2 a - g}$, the benzamide derivatives 1a-g were gently heated for few hours with $\mathrm{PCl}_{5}$ in anhydrous toluene, then treated with $N, N$-dimethylcyanamide $\left(\mathrm{Me}_{2} \mathrm{NCN}\right)$, and finally heated in the presence of $\mathrm{TiCl}_{4}$ in anhydrous toluene (Scheme 1).<smiles>[X]c1ccc(C(=O)Nc2ccc(C)cc2)cc1</smiles><smiles>[X]c1ccc(-c2nc(N(C)C)c3ccccc3n2)cc1</smiles>

$\begin{array}{lll}\text { 2a: } X=4-B r, & Y=H & (65 \%) \\ \text { 2b: } X=3-B r, & Y=H & (85 \%) \\ \text { 2c: } X=2-B r, & Y=H & (78 \%) \\ \text { 2d: } X=H, & Y=6-C l & (72 \%) \\ \text { 2e: } X=H, & Y=7-C l & (68 \%) \\ \text { 2f: } X=H, & Y=6-B r & (87 \%) \\ \text { 2g: } X=H, & Y=7-B r & (80 \%)\end{array}$

Scheme 1. Synthesis of 4-(N,N-dimethylamino)-2-phenylquinazoline derivatives (2a-g). Reagents and conditions: (i) $\mathrm{PCl}_{5}$, toluene, $50{ }^{\circ} \mathrm{C}$; (ii) $\mathrm{Me}_{2} \mathrm{NCN}$, toluene, $\mathrm{rt}, 24 \mathrm{~h}$; (iii) $\mathrm{TiCl}_{4}$, toluene, $70{ }^{\circ} \mathrm{C}, 5 \mathrm{~h}$.

Meanwhile, two other reagents for Suzuki cross-coupling reactions were synthesized, specifically, the appropriate boronic acid pinacol ester and the diboronic acid bis(pinacol) ester of 2,5-diphenyl-1,3,4-oxadiazole. These transformations involved the reaction of commercially-available 4-bromobenzoyl chloride (3) with either benzhydrazide (pathway A) or hydrazine hydrate (pathway B), in the presence of triethylamine. Subsequent heating of the crude $N, N^{\prime}$-diacylhydrazines $4 \mathbf{a}, \mathbf{b}$ with phosphorus oxychloride in a non-polar solvent generated the products, 2-(4-bromophenyl)-5-phenyl1,3,4-oxadiazole (5a) and 2,5-bis(4-phenyl)-1,3,4-oxadiazole (5b), which were then reacted with bis(pinacolato)diboron in dioxane overnight at $100{ }^{\circ} \mathrm{C}$ in the presence of potassium acetate as a base and $\left[1,1^{\prime}\right.$-bis(diphenylphosphino)ferrocene]dichloropalladium(II) $\mathrm{Pd}(\mathrm{dppf}) \mathrm{Cl}_{2}$ as a catalyst. The synthetic routes to obtaining boronic acid pinacol esters $(6,7)$ are presented in Scheme 2.<smiles>O=C(Cl)c1ccc(Br)cc1</smiles>

3<smiles>[Z]c1ccc(C(=O)NNC(=O)c2ccc(Br)cc2)cc1</smiles>

5a $\quad \mathrm{Z}=\mathrm{H} \quad(93 \%)$

5b $\quad Z=\operatorname{Br}(96 \%)$<smiles>CC1(C)OB(c2ccc(-c3nnc(-c4ccccc4)o3)cc2)OC1(C)C</smiles>

$6(85 \%)$

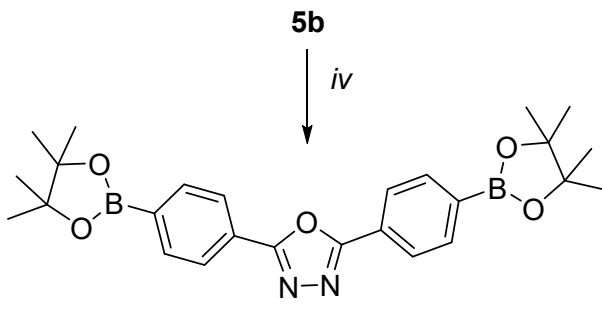

$7(92 \%)$

Scheme 2. Synthesis of boronic acid pinacol ester and diboronic acid bis(pinacol) ester of 2,5-diphenyl1,3,4-oxadiazole (6, 7). Reagents and conditions: (i) $\mathrm{PhCONHNH}_{2}, \mathrm{NEt}_{3}, \mathrm{CHCl}_{3}, 4 \mathrm{~h}$, rt; (ii) $\mathrm{N}_{2} \mathrm{H}_{4} \cdot \mathrm{H}_{2} \mathrm{O}$, $\mathrm{NEt}_{3}, \mathrm{CHCl}_{3}, 4 \mathrm{~h}$, rt; (iii) $\mathrm{POCl}_{3}$, toluene, reflux, 10 h; (iv) bis(pinacolato)diboron, 1,4-dioxane, AcOK, $\mathrm{Pd}(\mathrm{dppf}) \mathrm{Cl}_{2}$, sealed tube, $100{ }^{\circ} \mathrm{C}$, overnight. 
The final step involved the Suzuki cross-coupling reaction between halogen-containing quinazolines 2a-g and boronic derivatives, $\mathbf{6}$ and 7 . To obtain the best possible yields, the reaction conditions for the coupling reaction were optimized (Table 1). For this reason, boronic ester 6 and 4-(N,N-dimethylamino)-2-phenylquinazoline substituted with bromine at the para position of the 2-phenyl group (2a) were chosen as model reagents (Scheme 3).

Table 1. Initial optimization for the cross-coupling reaction to obtain $\mathbf{8 a}$.

\begin{tabular}{cccccc}
\hline Entry & Catalyst & Base & Solvent & PTC Catalyst & Yield [\%] ${ }^{\mathbf{a}}$ \\
\hline 1 & $\mathrm{Pd}\left(\mathrm{PPh}_{3}\right)_{4}$ & $\mathrm{Na}_{2} \mathrm{CO}_{3}$ & Toluene/water & Aliquat 336 & 63 \\
2 & $\mathrm{Pd}\left(\mathrm{PPh}_{3}\right)_{4}$ & $\mathrm{Na}_{2} \mathrm{CO}_{3}$ & Toluene/water & $\mathrm{BnEt}{ }_{3} \mathrm{NCl}$ & 61 \\
3 & $\mathrm{Pd}\left(\mathrm{PPh}_{3}\right)_{4}$ & $\mathrm{Na}_{2} \mathrm{CO}_{3}$ & Toluene/water & $\mathrm{Bu}{ }_{4} \mathrm{NCl}$ & 65 \\
4 & $\mathrm{Pd}\left(\mathrm{PPh}_{3}\right)_{4}$ & $\mathrm{Na}_{2} \mathrm{CO}_{3}$ & Toluene/water & $\mathrm{Bu}{ }_{4} \mathrm{NBr}$ & 68 \\
5 & $\mathrm{Pd}\left(\mathrm{t}-\mathrm{Bu}_{3} \mathrm{P}\right)_{2}$ & $\mathrm{Na}_{2} \mathrm{CO}_{3}$ & Toluene/water & $\mathrm{Bu}_{4} \mathrm{NBr}$ & 68 \\
6 & $\mathrm{Pd}(\mathrm{dppf}) \mathrm{Cl}_{2}$ & $\mathrm{Na}_{2} \mathrm{CO}_{3}$ & Toluene/water & $\mathrm{Bu}_{4} \mathrm{NBr}$ & 85 \\
7 & $\mathrm{Pd}\left(\mathrm{PPh}_{3}\right)_{2} \mathrm{Cl}_{2}$ & $\mathrm{Na}_{2} \mathrm{CO}_{3}$ & Toluene/water & $\mathrm{Bu}_{4} \mathrm{NBr}$ & 77 \\
8 & $\mathrm{Pd}(\mathrm{dppf}) \mathrm{Cl}_{2}$ & $\mathrm{~K}_{2} \mathrm{CO}_{3}$ & Toluene/water & $\mathrm{Bu} 4 \mathrm{NBr}$ & 60 \\
9 & $\mathrm{Pd}(\mathrm{dppf}) \mathrm{Cl}_{2}$ & $\mathrm{t}-\mathrm{BuOK}_{4}$ & Toluene/water & $\mathrm{Bu}_{4} \mathrm{NBr}$ & 70 \\
10 & $\mathrm{Pd}(\mathrm{dppf}) \mathrm{Cl}_{2}$ & $\mathrm{AcONa}_{2}$ & Toluene/water & $\mathrm{Bu}{ }_{4} \mathrm{NBr}$ & 66 \\
11 & $\mathrm{Pd}(\mathrm{dppf}) \mathrm{Cl}_{2}$ & $\mathrm{Na}_{2} \mathrm{CO}_{3}$ & Dioxane & - & 74 \\
12 & $\mathrm{Pd}(\mathrm{dppf}) \mathrm{Cl}_{2}$ & $\mathrm{Na}_{2} \mathrm{CO}_{3}$ & EtOH & - & 77 \\
13 & $\mathrm{Pd}(\mathrm{dppf}) \mathrm{Cl}_{2}$ & $\mathrm{Na}_{2} \mathrm{CO}_{3}$ & DME & - & 61 \\
14 & $\mathrm{Pd}(\mathrm{dppf}) \mathrm{Cl}_{2}$ & $\mathrm{Na}_{2} \mathrm{CO}_{3}$ & DMF & - & 64 \\
\hline
\end{tabular}

$\overline{\text { a Yield with respect to starting quinazoline 2a. Conditions: sealed tube, oil bath } 115^{\circ} \mathrm{C} \text {, overnight. }}$

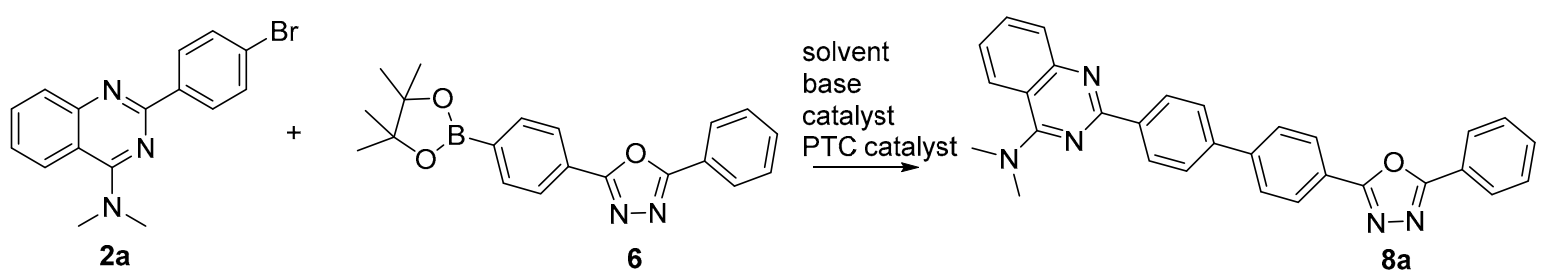

Scheme 3. Coupling of the model quinazoline 2a with monoboronic ester 6 .

The preliminary trials were conducted in a mixture of toluene and aqueous $\mathrm{Na}_{2} \mathrm{CO}_{3}$ solution in the presence of tetrakis(triphenylphosphine)palladium $(0) \mathrm{Pd}\left(\mathrm{PPh}_{3}\right)_{4}$, with a phase transfer catalyst (PTC), which allows regents transfer between two immiscible phases (toluene and water). Following the literature mentions regarding cross-coupling reactions assisted with phase transfer catalysts [59], three types of catalysts were tested: aliquat 336 [60], benzyltriethylammonium chloride $\left(\mathrm{BnEt}_{3} \mathrm{NCl}\right)$ [61], tetrabutylammonium chloride $\left(\mathrm{Bu}_{4} \mathrm{NCl}\right)$, or tetrabutylammonium bromide $\left(\mathrm{Bu}_{4} \mathrm{NBr}\right)$ [62] (Table 1, entries 1-4).

All reactions led to the formation of the desired quinazolinylphenyl-1,3,4-oxadiazole derivative $8 \mathrm{a}$ in similar yields (61-68\%); however, the optimal result of $68 \%$ was obtained using $\mathrm{Bu}_{4} \mathrm{NBr}$ as the PTC (Table 1, entry 4). During the search for the optimal conditions, various palladium catalysts, such as tetrakis(triphenylphosphine)palladium $(0)\left(\mathrm{Pd}\left(\mathrm{PPh}_{3}\right)_{4}\right)$, bis(tri-t-butylphosphine)palladium $(0)$ $\left(\mathrm{Pd}\left(\mathrm{t}-\mathrm{Bu}_{3} \mathrm{P}\right)_{2}\right),\left[1,1^{\prime}\right.$-bis(diphenylphosphino)ferrocene]palladium(II) dichloride $\left(\mathrm{Pd}(\mathrm{dppf}) \mathrm{Cl}_{2}\right)$, and bis(triphenylphosphine)palladium(II) dichloride $\left(\mathrm{Pd}\left(\mathrm{PPh}_{3}\right)_{2} \mathrm{Cl}_{2}\right)$ were also tested in toluene-water media in the presence of $\mathrm{Na}_{2} \mathrm{CO}_{3}$ as a base (Table 1, entries 4-7). In all cases, the product, 8a, was obtained in satisfactory yields, varying from 68 to $85 \%$. However, the catalytic system composed of $\mathrm{Pd}(\mathrm{dppf}) \mathrm{Cl}_{2}$ and $\mathrm{Bu}_{4} \mathrm{NBr}$ was the most effective combination, leading to a product yield of $85 \%$ (Table 1, entry 6). Additionally, other solvents, such as dioxane, ethanol, 1,2-dimethoxyethane (DME), and dimethylformamide (DMF) (Table 1, entries 11-14) were tested, but overall, the best results were achieved using a two-phase toluene-water mixture (Table 1, entry 6). Optimization of the 
synthetic conditions also required investigating the influence of the type of base used in the reaction, which participates in (i) halogen ion exchange involving the initial halide-containing reagent, 2a, at the surface of the catalyst, and (ii) activation of boronic ester, 6, to facilitate transmetalation. Among the different bases tested, including $\mathrm{Na}_{2} \mathrm{CO}_{3}, \mathrm{~K}_{2} \mathrm{CO}_{3}$, t-BuOK, and $\mathrm{AcONa}$, the best results were obtained after using $\mathrm{Na}_{2} \mathrm{CO}_{3}(85 \%$ yield; Table 1 , entry 6$)$. Therefore, these optimized reaction conditions were applied in the synthesis of unsymmetrical quinazolinylphenyl-1,3,4-oxadiazole derivatives (8a-c, 8f-g). The key boronic ester (6) reacted with various halogen-containing 4-(N,N-dimethylamino)-2-phenylquinazoline derivatives (2a-g) in the presence of $5 \mathrm{~mol} \%$ palladium catalyst $\left(\mathrm{Pd}(\mathrm{dppf}) \mathrm{Cl}_{2}\right), \mathrm{Na}_{2} \mathrm{CO}_{3}$, and $\mathrm{Bu}_{4} \mathrm{NBr}$ as a PTC catalyst, in the two-phase solvent system (toluene- $\mathrm{H}_{2} \mathrm{O}$ ). The mixtures were heated overnight in a sealed glass reactor, and the products were purified by extraction, followed by column chromatography and trituration. The results of the cross-coupling reactions are presented in Table 2 . This study afforded several novel unsymmetrical quinazolinylphenyl-1,3,4-oxadiazole derivatives (8a-c, $\mathbf{8 f - g}$ ) in satisfactory yields (72-86\%; Scheme 4).

Table 2. Synthesis of unsymmetrical quinazolinylphenyl-1,3,4-oxadiazole derivatives (8a-c, 8f-g) using Suzuki cross-coupling reactions.

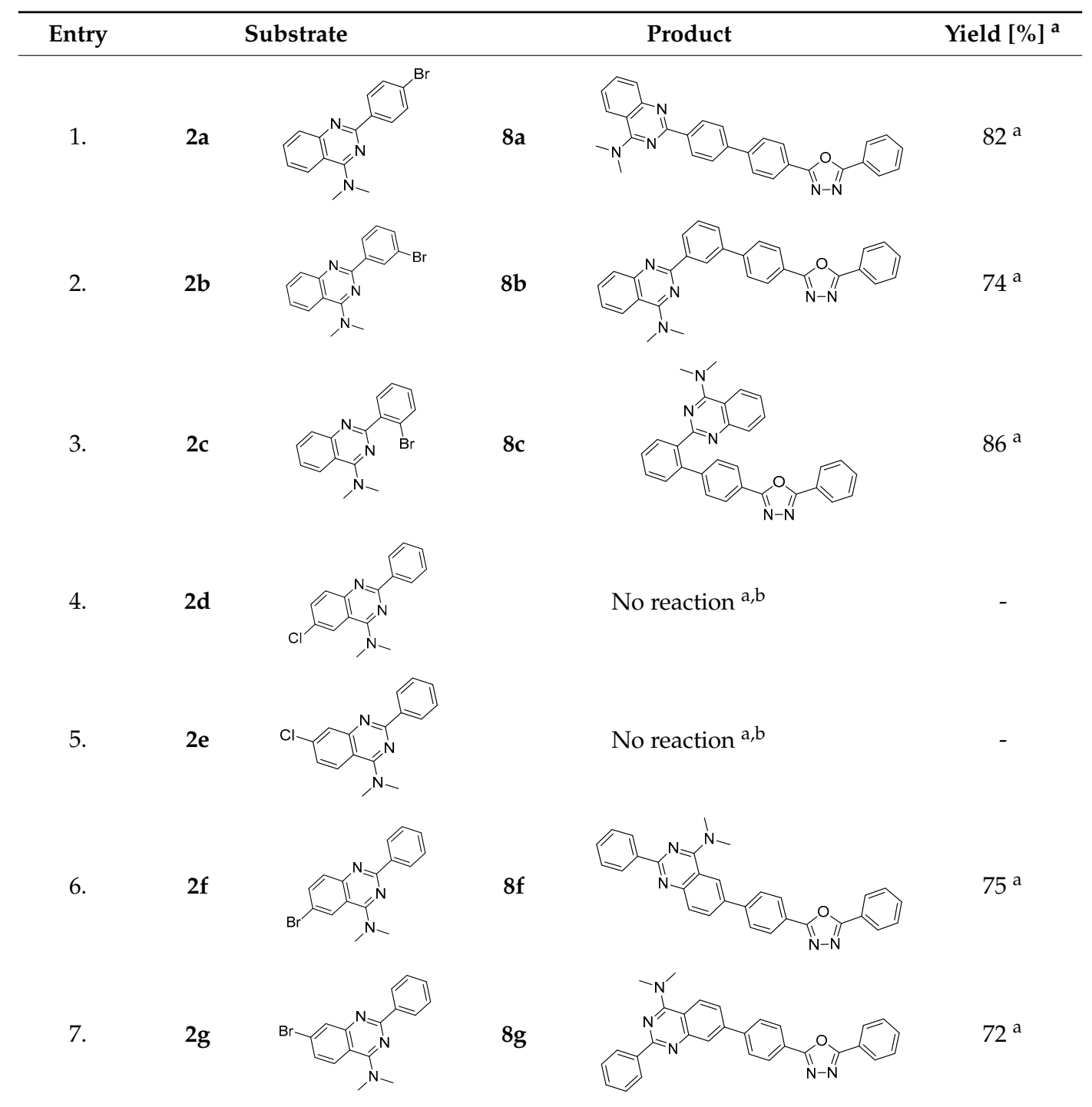

a Yield with respect to starting quinazoline derivative $\mathbf{2 a - c ,} \mathbf{2 f - g .}{ }^{b}$ For $\mathbf{2 d}$ and $\mathbf{2 f}$ additional experiments in MW, $120^{\circ} \mathrm{C}, 60 \mathrm{~min}$. 

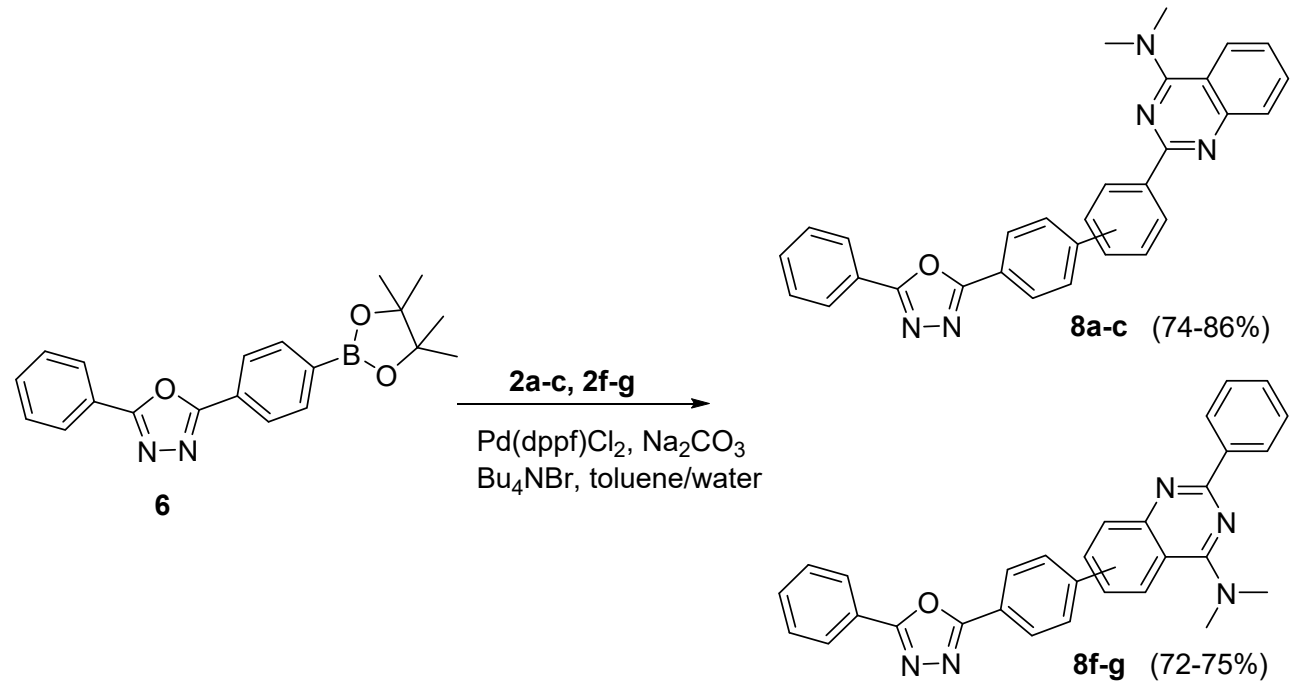

Scheme 4. Coupling of quinazoline derivatives (2a-c, $2 \mathrm{f}-\mathrm{g}$ ) with boronic ester 6 . Reagents and conditions: quinazoline derivative $2 \mathrm{a}-\mathrm{c}, \mathbf{2} \mathrm{f}-\mathrm{g}(0.31 \mathrm{mmol})$, boronic acid pinacol ester $\mathbf{6}(0.37 \mathrm{mmol}), \mathrm{Pd}(\mathrm{dppf})_{2}$ (0.015 mmol), $\mathrm{Bu}_{4} \mathrm{NBr}(0.03 \mathrm{mmol}), \mathrm{Na}_{2} \mathrm{CO}_{3}(1.53 \mathrm{mmol})$, toluene- $\mathrm{H}_{2} \mathrm{O}$ (3.3:1.7 mL), sealed tube, oil bath $115^{\circ} \mathrm{C}$, overnight.

Syntheses of quinazoline regioisomers $2 \mathbf{a}-2 \mathbf{c}$, substituted with bromine at the 2-phenyl ring position, were successful, and the products, $8 \mathbf{a}-\mathbf{c}$, were obtained in high yields (74-86\%; Table 2, entries 1-3). However, the yield of product, $\mathbf{8} \mathbf{b}$, which was derived from the meta-substituted arrangement (2b) was slightly lower ( $74 \%$; Table 2, entry 2$)$ than for products obtained from paraand ortho-substituted derivatives (82-86\%; Table 2, entries 1,3). These results can be explained based on the electron-withdrawing nature of the quinazoline scaffold adjacent to the phenyl ring. The same conditions were applied for 4-( $N, N$-dimethylamino)-2-phenylquinazolines $\mathbf{2 d}$, 2e substituted at positions 6 and 7 with chlorine atoms, where no conversion was observed (Table 2, entries 4,5). For the same substrates $\mathbf{2} \mathbf{d}, \mathbf{2 e}$, additional reactions in the microwave reactor were performed, but no positive outcomes were obtained. In contrast, the same coupling reactions conducted for the 6- and 7-bromide variations resulted in the formation of the desired products 8f-g in satisfactory yields (72-75\%; Table 2). This observation confirms the general trend in the reactivity of aryl halides in Suzuki cross-coupling reactions, where bromine derivatives are much more reactive than their chloride analogues.

Applying the described optimized conditions, another series of reactions was carried out with symmetrical diboronic acid bis(pinacol)ester, 7, and 4-( $N, N$-dimethylamine)-2-phenylquinazoline derivatives $\mathbf{2 a - c}, \mathbf{2} \mathbf{f}-\mathbf{g}$ in the presence of $10 \mathrm{~mol} \%$ palladium catalyst $\left(\mathrm{Pd}(\mathrm{dppf}) \mathrm{Cl}_{2}\right), \mathrm{Na}_{2} \mathrm{CO}_{3}$, and tetrabutylammonium bromide in the two-phase toluene-water solvent system (Scheme 5). The mixture was heated overnight in a sealed glass reactor, and the products were purified by extraction, followed by column chromatography and trituration.

The results are presented in Table 3. This study afforded novel, symmetrical 2,5-bis(quinazolinylphenyl)1,3,4-oxadiazole derivatives $\mathbf{9 a - c ,} 9 \mathbf{9 f - g}$ in satisfactory yields (50-70\%; Table 3 ). The best results were obtained for $9 \mathbf{a}$, where the diboronic precursor containing a 2,5-diphenyl-1,3,4-oxadiazole scaffold 7 was coupled to quinazoline arrangement, $2 \mathbf{a}$, with a 1,4-phenylene linker (70\%; Table 3, entry 2$)$. In general, the derivatives, 9a-c, exhibited a similar trend in yields, as was observed for the analogous mono-substituted entities 8a-c. Specifically, the meta derivative was produced in lower yield relative to the ortho- and para-substituted counterparts. It was also determined that the symmetrically substituted derivatives $\mathbf{9 a - c ,} \mathbf{9 f - g}$ were obtained in lower yields compared with the unsymmetrical arrangements $\mathbf{8 a - c}, \mathbf{8 f - g}$, because of their relatively lower solubility in most organic solvents, which complicated the purification procedure. 


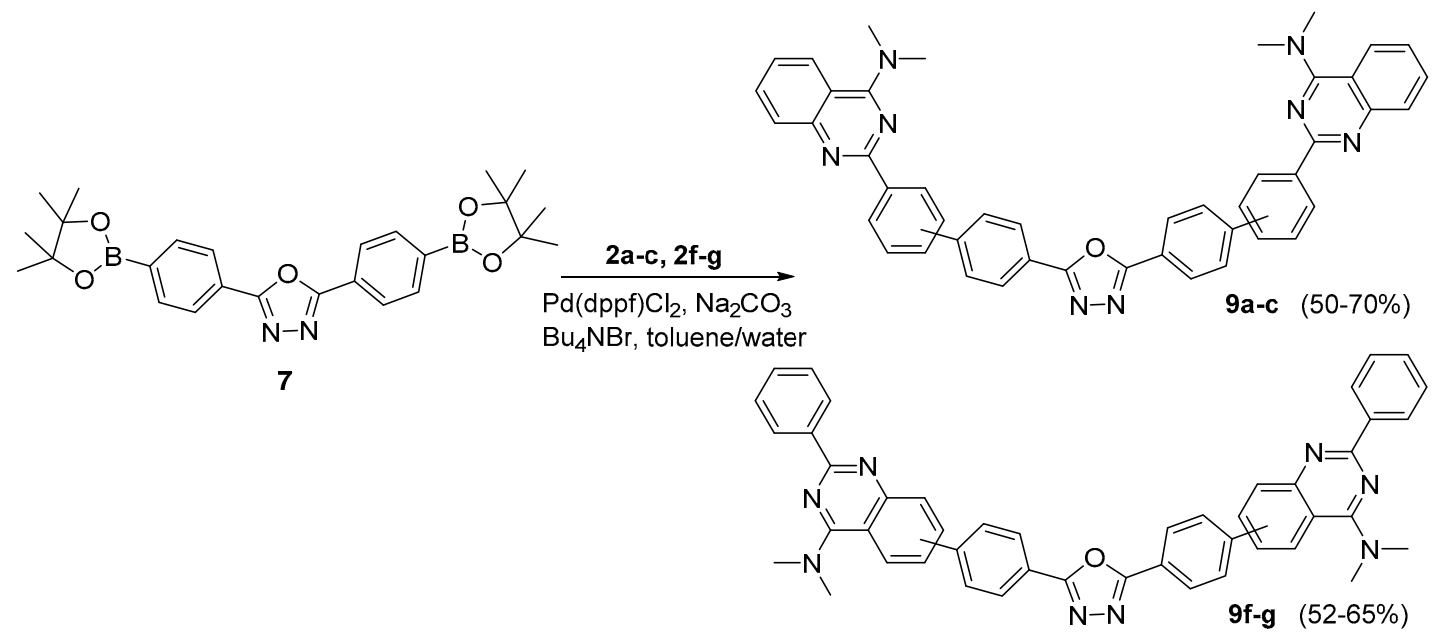

Scheme 5. Coupling of quinazoline derivatives (2a-c, $2 \mathrm{f}-\mathrm{g})$ with boronic ester $\mathbf{7}$. Reagents and conditions: quinazoline derivative $\mathbf{2 a - c}$, $2 \mathbf{f}-\mathbf{g}(0.50 \mathrm{mmol})$, diboronic acid bis(pinacol) ester $\mathbf{7}(0.28 \mathrm{mmol}), \mathrm{Pd}(\mathrm{dppf}) \mathrm{Cl}_{2}$ (0.021 mmol), $\mathrm{Bu}_{4} \mathrm{NBr}(0.042 \mathrm{mmol}), \mathrm{Na}_{2} \mathrm{CO}_{3}(2.11 \mathrm{mmol})$, toluene- $\mathrm{H}_{2} \mathrm{O}$ (6.6:3.4 mL), sealed tube, oil bath $115^{\circ} \mathrm{C}$, overnight.

Table 3. Synthesis of symmetrical 2,5-bis(quinazolinylphenyl)-1,3,4-oxadiazole derivatives (9a-c, 9f-g) using Suzuki cross-coupling reactions.

\begin{tabular}{|c|c|c|c|c|}
\hline Entry & Substrate & & Product & Yield [\%] ${ }^{a}$ \\
\hline 1. & $2 a$ & $9 a$ & & 70 \\
\hline 2. & $2 b$ & $9 b$ & & 50 \\
\hline 3. & $2 c$ & $9 c$ & & 60 \\
\hline 4. & $2 d$ & & No reactior & - \\
\hline 5. & $2 e$ & & No reaction & - \\
\hline 6. & $2 f$ & $9 f$ & & 52 \\
\hline 7. & $2 \mathrm{~g}$ & $9 g$ & & 65 \\
\hline
\end{tabular}

a Yield with respect to starting quinazoline derivative 2a-c, 2 f-g. 
The structures of unsymmetrical and symmetrical quinazolinylphenyl-1,3,4-oxadiazole derivatives 8a-c, 8f-g, 9a-c, 9f-g obtained following Suzuki cross-coupling reactions involving the boronic precursors 6, 7 containing a 1,3,4-oxadiazole scaffold were confirmed using typical spectroscopic methods (nuclear magnetic resonance spectroscopy ${ }^{1} \mathrm{H}$ - and ${ }^{13} \mathrm{C}-\mathrm{NMR}$, UV-Vis spectrometry, high resolution mass spectrometry HRMS, infrared spectroscopy IR, see Supplementary Materials).

In the ${ }^{1} \mathrm{H}-\mathrm{NMR}$ spectra of unsymmetrical (compounds 8a-c, 8f-g) and symmetrical quinazolinylphenyl1,3,4-oxadiazole derivatives (compounds 9a-c, 9f-g), characteristic signals from the dimethylamino group are observed in the range between $2.94-3.55 \mathrm{ppm}$.

Two protons from the phenyl group for $\mathbf{8 a - b}, \mathbf{8 f - g}$ and $\mathbf{9 a}-\mathbf{b}, \mathbf{9 f - g}$, substituted at the quinazoline moiety, are shifted to lower field, and appear in the range between $8.50-8.90 \mathrm{ppm}$. In the remaining derivatives, $8 \mathrm{c}$ and $9 \mathrm{c}$, these protons are observed in the range of $8.15-8.18 \mathrm{ppm}$. Such significant changes in chemical shifts are likely due to the proximity of these protons to the electronegative nitrogen atoms. In the ${ }^{13} \mathrm{C}-\mathrm{NMR}$ spectra, the characteristic signals from the dimethylamino group are observed in the narrow range between 41.4-42.1 ppm. The unsymmetrical quinazolinylphenyl-1,3,4-oxadiazole derivatives (8a-c, 8f-g), have four distinctive signals from the two quaternary quinazoline carbons C-4a and C-8a, as well as carbon atoms C-2 and C-5 of the 1,3,4-oxadiazole ring, which appear in the range of 158.7-164.7 ppm. However, in the symmetrical quinazolinylphenyl-1,3,4-oxadiazole derivatives (9a-c, 9f-g) the signals range from 158.9 to $164.7 \mathrm{ppm}$. Both the ${ }^{1} \mathrm{H}$ - and ${ }^{13} \mathrm{C}-\mathrm{NMR}$ spectra of 2,5-bis(4-arylphenyl)-1,3,4-oxadiazoles (9a-c, 9f-g) display a reduced number of peaks due to the symmetrical nature of these compounds' structures.

UV-Vis spectra of the investigated compounds $8 \mathbf{a}-\mathbf{c}, \mathbf{8 f}-\mathbf{g}, \mathbf{9 a - c}, \mathbf{9 f - g}$, measured in dichloromethane $(\mathrm{DCM})$, or methanol $(\mathrm{MeOH})$ revealed the presence of three, four or five absorption maxima, depending on the symmetry and structure of the connection between the 1,3,4-oxadiazole moiety and the 4-N,N-dimethylaminoquinazoline scaffold. Longwave absorption bands $\left(n \rightarrow \pi^{*}\right)$ of the symmetrical 9a-c, 9f-g and unsymmetrical 8a-c, $8 \mathbf{f}-\mathbf{g}$ quinazoline derivatives were located in the range of 302-361 nm and characterized by high absorption coefficients, comparable to $\pi \rightarrow \pi^{*}$ absorption bands. The fluorescence spectra of the studied compounds $\mathbf{8 a - c , ~} \mathbf{8 f - g}, \mathbf{9 a - c}, \mathbf{9 f - g}$ are generally complex and composed of multiple individual signals with considerable Stokes shifts $(\Delta)$, varying from 58 to $131 \mathrm{~nm}$ (Table 4).

Table 4. Absorption and fluorescence spectral parameters of the investigated compounds, 6, 7, 8a-c, $8 f-g, 9 a-c, 9 f-g$.

\begin{tabular}{|c|c|c|c|c|c|c|}
\hline Entry & Compound & $\begin{array}{c}\text { Absorption Maximum } \\
\lambda_{\max }[\mathrm{nm}] \\
\left.\left(\varepsilon .10^{-4} \mathrm{~m}^{3} /(\mathrm{mol} . \mathrm{cm})\right]\right)\end{array}$ & $\begin{array}{l}\text { Excitation } \\
\text { Wavelength } \\
\lambda_{\mathrm{ex}}[\mathrm{nm}]\end{array}$ & $\begin{array}{c}\text { Emission } \\
\text { Wavelength } \\
\lambda_{\mathrm{em}}[\mathrm{nm}]\end{array}$ & $\begin{array}{l}\text { Stokes } \\
\text { Shift }^{\text {a }} \Delta \\
\text { [nm] }\end{array}$ & $\begin{array}{c}\text { Quantum } \\
\text { Yield }^{b} \\
\Phi_{\mathrm{f}}\end{array}$ \\
\hline 2. & 7 & $298(2.97)$ & 300 & 333,349 (max), 364 & 51 & 0.91 \\
\hline 3. & $8 a$ & $329(4.98)$ & 330 & 414 & 85 & 0.01 \\
\hline 4. & $8 b$ & $305(4.37)$ & 310 & 365 (max), 385 & 60 & 0.02 \\
\hline 6. & $8 f$ & $297(5.63)$ & 300 & 429 & 131 & 0.61 \\
\hline 7. & $8 g$ & $314(7.44)$ & 315 & 419 & 105 & 0.08 \\
\hline 8. & $9 a$ & $342(6.91)$ & 340 & 424 & 82 & 0.05 \\
\hline 9. & $9 b$ & $320(8.46)$ & 320 & 378 (max), 397 & 58 & 0.01 \\
\hline 10. & $9 c$ & $319(4.78)$ & 320 & 427 & 108 & 0.01 \\
\hline
\end{tabular}

${ }^{a}$ Stokes shift were calculated from the equation $\Delta=\lambda_{\mathrm{em}}-\lambda_{\max } ;{ }^{\mathrm{b}}$ the quantum yields $\Phi_{\mathrm{f}}$ were calculated at $\lambda_{\mathrm{ex}}=355 \mathrm{~nm}$ in cyclohexane in comparison to DPA $\left(\Phi_{\mathrm{f}}=0.97\right)$ and at $\lambda_{\mathrm{ex}}=320 \mathrm{~nm}$ in $n$-hexane in comparison to $\operatorname{DPB}\left(\Phi_{\mathrm{f}}=0.35\right)$ - the mean value is presented.

The quantum yields $\left(\Phi_{\mathrm{f}}\right)$ were determined based on two standards (i.e., 1,4-diphenylbuta-1,3-diene (DPB) and 9,10-diphenylanthracene (DPA) in non-polar solvents [63,64], according to the method described by Brouwer [65]. The analysis of Stokes shifts showed that the quinazolinylphenyl-1,3,4- 
oxadiazoles 8a-c, 8f-g, representing the series of unsymmetrical arrangements composed of six conjugated and fused aromatic rings, exhibited relatively higher values of Stokes shifts (60-131 nm, Table 4, entries 3-7) in contrast to the corresponding symmetrical derivatives $\mathbf{9 a - c , ~} \mathbf{9 f}-\mathbf{g}$, containing the more extended arrangement of nine aromatic rings (58-108 nm, Table 4, entries 8-12). Moreover, the introduction of the additional aromatic rings of 4-N,N-dimethylamino-2-phenylquinazoline scaffold, and the lenghtening of the conjugation in 9a-c, 9f-g series did not lead to both a significant increase in Stokes shifts and quantum yields, except for the symmetrical derivative 9f (Table 4, entry 11). Generally, the highest quantum yields were achieved for the unsymmetrical $\mathbf{8 f}$ and symmetrical $9 \mathbf{f}$ compounds $(0.61$ and 0.98 respectively, Table 4, entries 6,11 ), in which the 1,3,4-oxadiazole moiety is connected to the quinazoline by a 1,4-phenylene linker at the 6 position, which allowed effective electron transfer between these two heterocyclic moieties. Noteworthy is the fact that the irradiation of $\mathbf{8 f}$ by UV radiation led to violet fluorescence that was visible to the naked eye. It is important to note that the boronic acid pinacol ester and diboronic acid bis(pinacol) ester of 2,5-diphenyl-1,3,4-oxadiazole $(6,7)$ starting compounds, which play a role in building the scaffolds for the studied conjugated arrangements, also had high quantum yields ( 0.68 for 6 , and 0.91 for 7 ; Table 4 , entries 1,2$)$. However, the other products formed from the conjugation of boronic esters $(6,7)$ to quinazolines containing a $N, N$-dimethylamino group did not exhibit increased quantum yields. In fact, they caused fluorescence quenching, such that their quantum yields did not exceed 0.13 (8a-c, 8g, 9a-c, 9g; Table 4, entries 3-5,7,8-10,12). A survey of the literature revealed that electron-rich species, including substituted amino groups that can donate electrons to aromatic heterocycles (i.e., fluorophores), can act as potential fluorescence quenchers [66]. They are responsible for the formation of charge transfer complexes, which often return to the ground state without emitting a photon.

\section{Materials and Methods}

\subsection{General Information}

All solvents and reagents were purchased from commercial sources and were used without additional purification. Melting points ( $\mathrm{mp}$ ) were measured using a SMP3 melting point apparatus (Stuart, Staffordshire, UK) and are uncorrected. UV-Vis spectra were recorded on a Jasco V-650 (Jasco Corporation, Tokyo, Japan) or a U-3900H spectrophotometer (Hitachi, Tokyo, Japan). Elemental analysis were performed with a VarioEL analyser (Elementar UK Ltd., Stockport, UK). ${ }^{1} \mathrm{H}-(400 \mathrm{MHz})$ and ${ }^{13} \mathrm{C}-\mathrm{NMR}$ spectra $(101 \mathrm{MHz})$ were recorded in $\mathrm{CDCl}_{3}$ solutions using TMS as internal standard on an Agilent 400-NMR spectrometer (Agilent Technologies, Waldbronn, Germany). Thin layer chromatography (TLC) was performed on silica gel $60 \mathrm{~F}_{254}$ TLC plates (Merck KGaA, Darmstadt, Germany) using benzene-EtOAc (3:1), DCM-EtOAc (9:1), DCM-MeOH (95:5) as the mobile phases. FT-IR spectra were recorded between 4000 and $6500 \mathrm{~cm}^{-1}$ on a Nicolet $6700 \mathrm{FT}$-IR apparatus (Thermo Fischer Scientific, Wesel, Germany) equipped with a Smart iTR accessory. High-resolution mass spectra (HRMS) were acquired on an Ultra-High Resolution (UHR) mass spectrometer Impact II $^{\mathrm{TM}}$ QTOF instrument (Bruker, Bremen, Germany) equipped with an electrospray ionization (ESI) source, using $\mathrm{MeOH}$ or DCM as a solvent. Fluorescence spectra were recorded in DCM solution using a Hitachi F-7000 fluorescence spectrophotometer (Hitachi Ltd., Tokyo, Japan) at room temperature.

\subsection{Synthesis and Characterization}

3.2.1. General Procedure for Preparing 4-(N,N-dimethylamino)-2-phenylquinazoline Derivatives 2a-g

The appropriate benzamide derivative $(0.025 \mathrm{~mol})$ : $N$-phenyl-4-bromobenzamide (1a), $N$-phenyl-3-bromobenzamide (1b), N-phenyl-2-bromobenzamide (1c), $N$-(4-chlorophenyl)-benzamide (1d), N-(3-chlorophenyl)benzamide (1e), N-(4-bromophenyl)benzamide (1f) or N-(3-bromophenyl) benzamide $(\mathbf{1 g})$ and $\mathrm{PCl}_{5}(5.75 \mathrm{~g} ; 0.028 \mathrm{~mol})$ were gently heated in anhydrous toluene $(50 \mathrm{~mL})$ at about $50{ }^{\circ} \mathrm{C}$ until the benzamide derivative was completely consumed (based on TLC, 3-6 h). The mixture 
was concentrated on a rotary evaporator to remove toluene and $\mathrm{POCl}_{3}$. Anhydrous toluene $(50 \mathrm{~mL})$ and $\mathrm{N}, \mathrm{N}$-dimethylcyanamide $(1.75 \mathrm{~g} ; 2.0 \mathrm{~mL} ; 0.025 \mathrm{~mol})$ were added, and the mixture was left for $24 \mathrm{~h}$ at room temperature before dropwise addition of a solution of $\mathrm{TiCl}_{4}(2.5 \mathrm{~mL} ; 0.025 \mathrm{~mol})$ in $10 \mathrm{~mL}$ of anhydrous toluene. The mixture was agitated at elevated temperature $\left(70{ }^{\circ} \mathrm{C}\right)$ for $5 \mathrm{~h}$. After cooling, the solvent was decanted from the gluey solid, and $100 \mathrm{~mL}$ of $20 \%$ aqueous $\mathrm{HCl}$ added. The hydrolyzed mixture was filtered, and the resulting solution was neutralized with $20 \%$ aqueous $\mathrm{NaOH}$. The precipitate was extracted with chloroform $(3 \times 20 \mathrm{~mL})$, dried and concentrated. The crude products were purified by column chromatography (silica gel, eluent: benzene-EtOAc, 3:1) to yield the appropriate 4-(N,N-dimethylamino)-2-phenylquinazoline derivatives $\mathbf{2 a - g}$.

2-(4-Bromophenyl)-4-(N,N-dimethylamino)quinazoline (2a). The product was obtained as a colourless solid (5.33 g, 65\%); mp 104-105 ${ }^{\circ} \mathrm{C}\left(108-110{ }^{\circ} \mathrm{C}\right.$ [67]); $R_{f}=0.54$ (benzene-EtOAc, 3:1).

2-(3-Bromophenyl)-4-(N,N-dimethylamino)quinazoline (2b). The product was obtained as a colourless solid $(6.97 \mathrm{~g}, 85 \%) ; \mathrm{mp} 82-84{ }^{\circ} \mathrm{C} ; R_{f}=0.52$ (benzene-EtOAc, 3:1). ${ }^{1} \mathrm{H}-\mathrm{NMR}\left(\mathrm{CDCl}_{3}\right): \delta=3.42(\mathrm{~s}, 6 \mathrm{H})$; $7.33(\mathrm{t}, J=7.6 \mathrm{~Hz}, 1 \mathrm{H}) ; 7.37(\mathrm{t}, J=8.4 \mathrm{~Hz}, 1 \mathrm{H}) ; 7.56(\mathrm{~d}, J=7.6 \mathrm{~Hz}, 1 \mathrm{H},) ; 7.69(\mathrm{t}, J=8.8 \mathrm{~Hz}, 1 \mathrm{H}) ; 7.91$ $(\mathrm{d}, J=8.4 \mathrm{~Hz}, 1 \mathrm{H}) ; 8.00(\mathrm{~d}, J=8.8 \mathrm{~Hz}, 1 \mathrm{H}) ; 8.49(\mathrm{~d}, J=7.6 \mathrm{~Hz}, 1 \mathrm{H}) ; 8.70(\mathrm{~s}, 1 \mathrm{H}) .{ }^{13} \mathrm{C}-\mathrm{NMR}\left(\mathrm{CDCl}_{3}\right)$ : $\delta=41.8 ; 115.0 ; 122.5 ; 124.3 ; 125.5 ; 126.9 ; 128.7 ; 129.7 ; 131.3 ; 132.0 ; 141.0 ; 152.8 ; 157.8 ; 163.8$. Anal. Calcd for $\mathrm{C}_{16} \mathrm{H}_{14} \mathrm{~N}_{3} \mathrm{Br}$ : C, 58.55; H, 4.30; N, 12.80. Found: C, 58.49; H, 4.26; N, 12.82.

2-(2-Bromophenyl)-4-(N,N-dimethylamino)quinazoline (2c). The product was obtained as a colourless solid $(6.40 \mathrm{~g}, 78 \%)$; mp $148-150{ }^{\circ} \mathrm{C} ; R_{f}=0.56$ (benzene-EtOAc, $\left.3: 1\right) .{ }^{1} \mathrm{H}-\mathrm{NMR}\left(\mathrm{CDCl}_{3}\right): \delta=3.41(\mathrm{~s}, 6 \mathrm{H})$; $7.24(\mathrm{t}, J=7.6 \mathrm{~Hz}, 1 \mathrm{H}) ; 7.39(\mathrm{t}, J=8.8 \mathrm{~Hz}, 1 \mathrm{H}) ; 7.41(\mathrm{t}, J=7.6 \mathrm{~Hz}, 1 \mathrm{H}) ; 7.67(\mathrm{~d}, J=7.6 \mathrm{~Hz}, 1 \mathrm{H}) ; 7.72$ $(\mathrm{t}, J=7.2 \mathrm{~Hz}, 1 \mathrm{H}) ; 7.82(\mathrm{~d}, J=7.2 \mathrm{~Hz}, 1 \mathrm{H}) ; 7.94(\mathrm{~d}, J=8.8 \mathrm{~Hz}, 1 \mathrm{H}) ; 8.05(\mathrm{~d}, J=7.2 \mathrm{~Hz}, 1 \mathrm{H}) .{ }^{13} \mathrm{C}-\mathrm{NMR}$ $\left(\mathrm{CDCl}_{3}\right): \delta=41.9 ; 114.5 ; 121.8 ; 124.5 ; 125.4 ; 127.2 ; 128.6 ; 129.7 ; 131.5 ; 132.0 ; 133.6 ; 140.9 ; 152.4 ; 161.1$; 163.3. Anal. Calcd for $\mathrm{C}_{16} \mathrm{H}_{14} \mathrm{~N}_{3} \mathrm{Br}$ : C, 58.55; H, 4.30; N, 12.80. Found: $\mathrm{C}, 58.50 ; \mathrm{H}, 4.28 ; \mathrm{N}, 12.84$.

6-Chloro-4-(N,N-dimethylamino)-2-phenylquinazoline (2d). The product was obtained as a colourless solid (5.10 g, 72\%); mp 95-97 ${ }^{\circ} \mathrm{C}\left(94-96{ }^{\circ} \mathrm{C}[68]\right) ; R_{f}=0.62$ (benzene-EtOAc, 3:1).

7-Chloro-4-(N,N-dimethylamino)-2-phenylquinazoline (2e). The product was obtained as a beige solid $(4.82 \mathrm{~g}, 68 \%) ; \mathrm{mp} 138-139{ }^{\circ} \mathrm{C} ; R_{f}=0.59$ (benzene-EtOAc, 3:1). ${ }^{1} \mathrm{H}-\mathrm{NMR}\left(\mathrm{CDCl}_{3}\right): \delta=3.39(\mathrm{~s}, 6 \mathrm{H}) ; 7.24$ $(\mathrm{d}, J=8.8 \mathrm{~Hz}, 1 \mathrm{H}) ; 7.46-7.48(\mathrm{~m}, 3 \mathrm{H}) ; 7.80-7.90(\mathrm{~m}, 2 \mathrm{H}) ; 8.52(\mathrm{~d}, J=8.0 \mathrm{~Hz}, 2 \mathrm{H}) .{ }^{13} \mathrm{C}-\mathrm{NMR}\left(\mathrm{CDCl}_{3}\right)$ : $\delta=41.7 ; 113.1 ; 124.6 ; 126.8 ; 127.6 ; 128.2 ; 128.4 ; 130.2 ; 137.8 ; 138.5 ; 153.9 ; 160.1 ; 163.3$. Anal. Calcd for $\mathrm{C}_{16} \mathrm{H}_{14} \mathrm{~N}_{3} \mathrm{Cl}: \mathrm{C}, 67.72 ; \mathrm{H}, 4.97 ; \mathrm{N}, 14.81$. Found: $\mathrm{C}, 67.68 ; \mathrm{H}, 4.95 ; \mathrm{N}, 14.76$.

6-Bromo-4-(N,N-dimethylamino)-2-phenylquinazoline (2f). The product was obtained as a yellowish solid (7.14 g, 87\%); mp 101-102 ${ }^{\circ} \mathrm{C}\left(99-100{ }^{\circ} \mathrm{C}[68]\right) ; R_{f}=0.56$ (benzene-EtOAc, 3:1).

7-Bromo-4-(N,N-dimethylamino)-2-phenylquinazoline $(\mathbf{2 g})$. The product was obtained as a colourless solid $(6.56 \mathrm{~g}, 80 \%) ; \mathrm{mp} 135-136{ }^{\circ} \mathrm{C} ; R_{f}=0.50$ (benzene-EtOAc, 3:1). ${ }^{1} \mathrm{H}-\mathrm{NMR}\left(\mathrm{CDCl}_{3}\right): \delta=3.39(\mathrm{~s}, 6 \mathrm{H}) ; 7.39$ $(\mathrm{d}, J=8.8 \mathrm{~Hz}, 1 \mathrm{H}) ; 7.44-7.49(\mathrm{~m}, 3 \mathrm{H}) ; 7.81(\mathrm{~d}, J=8.8 \mathrm{~Hz}, 1 \mathrm{H}) ; 8.10(\mathrm{~s}, 1 \mathrm{H}) ; 8.51-8.54(\mathrm{~m}, 2 \mathrm{H}) .{ }^{13} \mathrm{C}-\mathrm{NMR}$ $\left(\mathrm{CDCl}_{3}\right): \delta=41.7 ; 113.4 ; 126.3 ; 126.8 ; 127.1 ; 128.2 ; 128.4 ; 130.3 ; 130.9 ; 138.4 ; 153.9 ; 159.9 ; 163.4$. Anal. Calcd for $\mathrm{C}_{16} \mathrm{H}_{14} \mathrm{~N}_{3} \mathrm{Br}$ : C, 58.55; H, 4.30; N, 12.80. Found: C, 58.57; H, 4.33; N, 12.85 .

\subsubsection{Preparation of 2-(4-Bromophenyl)-5-phenyl-1,3,4-oxadiazole (5a)—Pathway A}

4-Bromobenzoyl chloride $(3,10.98 \mathrm{~g}, 0.05 \mathrm{~mol})$ was added to a magnetically agitated solution of benzhydrazide $(6.81 \mathrm{~g}, 0.05 \mathrm{~mol})$ and triethylamine $(7.0 \mathrm{~mL}, 0.05 \mathrm{~mol})$ in $100 \mathrm{~mL}$ of chloroform, which was placed in an ice bath, and once the addition was complete, the mixture was stirred for $4 \mathrm{~h}$ at room temperature. The solid precipitate was collected by filtration, washed with hexane $(50 \mathrm{~mL})$ and a large quantity of water $(200 \mathrm{~mL})$, air-dried, yielding $12.60 \mathrm{~g}$ (79\% yield) of pure $N^{\prime}$-benzoyl-4-bromobenzohydrazide (4a). The crude intermediate, $4 \mathbf{a}$, was treated with phosphorous oxychloride $(25 \mathrm{~mL}, 0.27 \mathrm{~mol}$ ) and added to $100 \mathrm{~mL}$ of dry toluene, and the mixture was refluxed until the initial 4a was fully consumed (based on TLC, 10 h). After cooling, it was concentrated, and the 
precipitated crystals were filtered off to give pure 2-(4-bromophenyl)-5-phenyl-1,3,4-oxadiazole (5a). Colourless crystals (11.05 g, 93\%); $\mathrm{mp} 169-170{ }^{\circ} \mathrm{C}\left(169-170{ }^{\circ} \mathrm{C}\right.$ [69]); $\mathrm{R}_{f}=0.60$ (benzene-EtOAc, 3:1).

\subsubsection{Preparation of 2,5-bis(4-Bromophenyl)-1,3,4-oxadiazole (5b)-Pathway B}

4-Bromobenzoyl chloride $(3,21.95 \mathrm{~g}, 0.10 \mathrm{~mol})$ was added to a magnetically agitated solution of hydrazine hydrate $(2.4 \mathrm{~mL}, 0.05 \mathrm{~mol})$ and triethylamine $(13.9 \mathrm{~mL}, 0.10 \mathrm{~mol})$ in $100 \mathrm{~mL}$ of chloroform, which was placed in an ice bath. After the addition, the mixture was stirred for $4 \mathrm{~h}$ at room temperature. The solid precipitate was collected by filtration, washed with hexane $(50 \mathrm{~mL})$ and a large quantity of water $(200 \mathrm{~mL})$, and air-dried, yielding $13.53 \mathrm{~g}$ ( $68 \%$ yield) of pure $N, N^{\prime}$-bis(4-bromobenzoyl)hydrazine (4b). The crude intermediate, $4 \mathbf{b}$, was treated with phosphorous oxychloride $(25 \mathrm{~mL}, 0.27 \mathrm{~mol})$ and added to $100 \mathrm{~mL}$ of dry toluene, and the mixture was refluxed until the starting material, $4 \mathbf{b}$, was fully consumed (based on TLC, $10 \mathrm{~h}$ ). After cooling, it was concentrated, and the precipitated crystals were filtered off to give pure 2,5-bis(4-bromophenyl)-1,3,4-oxadiazole (5b). Colourless crystals (12.40 g, $96 \%) ; \mathrm{mp} 259^{\circ} \mathrm{C}\left(258^{\circ} \mathrm{C}[70]\right) ; \mathrm{R} f=0.62$ (benzene-EtOAc, 3:1).

\subsubsection{Preparation of 2-Phenyl-5-[4-(tetramethyl-1,3,2-dioxaborolan-2-yl)phenyl]-1,3,4-oxadiazole (6)}

Bis(pinacolato)diboron $(2.42 \mathrm{~g} ; 0.0095 \mathrm{~mol})$ and $\mathrm{AcOK}(1.95 \mathrm{~g} ; 0.020 \mathrm{~mol})$ were added to a degassed 1,4-dioxane (15 mL) solution of 2,5-bis(4-bromophenyl)-1,3,4-oxadiazole (5b) (1.50 g; $0.004 \mathrm{~mol})$ in a glass tube reactor. The mixture was bubbled with $\mathrm{Ar}$ for $15 \mathrm{~min}$, and then $\mathrm{Pd}(\mathrm{dppf}) \mathrm{Cl}_{2}(0.15 \mathrm{~g} ; 0.0002$ mol) was added. The glass tube reactor was sealed, and the reaction was stirred at $100{ }^{\circ} \mathrm{C}$ overnight. The solvent was evaporated, and the residue was portioned between DCM and $\mathrm{H}_{2} \mathrm{O}$. The resulting mixture was extracted with DCM twice $(2 \times 30 \mathrm{~mL})$. The final product was purified by column chromatography (silica gel, eluent: $0-10 \%$ EtOAc in DCM), followed by trituration with $n$-hexane to obtain $1.48 \mathrm{~g}$ of pure product 6 . Cream solid $(1.48 \mathrm{~g}, 85 \%) ; \mathrm{mp} 167^{\circ} \mathrm{C} ; \mathrm{R}_{f}=0.59$ (DCM-EtOAc, 9:1). IR (ATR): 2975, 1614, 1571, 1541, 1485, 1393, 1407, 1354, 1331, 1269, 1211, 1141, 1114, 1089, 1069, 1026, 1016, 964, 890, 847, 821, 776, 717, 700, 690, $667 \mathrm{~cm}^{-1} .{ }^{1} \mathrm{H}-\mathrm{NMR}\left(\mathrm{CDCl}_{3}\right): \delta=8.23-8.06(\mathrm{~m}, 4 \mathrm{H}), 8.03-7.92$ $(\mathrm{m}, 2 \mathrm{H}), 7.61-7.49(\mathrm{~m}, 3 \mathrm{H}), 1.38(\mathrm{~s}, 12 \mathrm{H}) .{ }^{13} \mathrm{C}-\mathrm{NMR}\left(\mathrm{CDCl}_{3}\right) \delta=164.8,164.8,135.5,131.9,129.2,127.1$, 126.2, 126.1, 124.1, 84.4, 67.2, 25.0. HRMS (ESI/Q-TOF) $m / z:[\mathrm{M}+\mathrm{H}]^{+}$calcd for $\mathrm{C}_{20} \mathrm{H}_{22} \mathrm{BN}_{2} \mathrm{O}_{3} 349.1718$; found 349.1755. UV (MeOH): $\lambda_{\max }(\varepsilon)=203.5$ (26630), 237.5 (7930), 287.5 (32610).

\subsubsection{Preparation of bis[4-(Tetramethyl-1,3,2-dioxaborolan-2-yl)phenyl]-1,3,4-oxadiazole (7)}

Bis(pinacolato)diboron $(2.42 \mathrm{~g} ; 0.0095 \mathrm{~mol})$ and AcOK ( $1.95 \mathrm{~g} ; 0.020 \mathrm{~mol})$ were added to a degassed 1,4-dioxane $(15 \mathrm{~mL})$ solution of 2,5-bis(4-bromophenyl)-1,3,4-oxadiazole (5b) (1.50 g; $0.004 \mathrm{~mol})$ in a glass tube reactor. The mixture was bubbled with Ar for $15 \mathrm{~min}$, and then $\mathrm{Pd}(\mathrm{dppf}) \mathrm{Cl}_{2}(0.15 \mathrm{~g}$; $0.0002 \mathrm{~mol}$ ) was added. The glass tube reactor was sealed, and the reaction was stirred at $100{ }^{\circ} \mathrm{C}$ overnight. The solvent was evaporated, and the residue was portioned between DCM and $\mathrm{H}_{2} \mathrm{O}$. The resulting mixture was extracted with DCM twice $(2 \times 30 \mathrm{~mL})$. The final product was purified by column chromatography (silica gel, eluent: 0-10\% EtOAc in DCM), followed by trituration with $n$-hexane to obtain $1.73 \mathrm{~g}$ of pure product 7 . Pink pale solid (1.73 g, 92\%); mp $248^{\circ} \mathrm{C}$ (decomp.) (249 ${ }^{\circ} \mathrm{C}$ [24]); $\mathrm{R}_{f}=0.51$ (DCM-EtOAc, 9:1). IR (ATR): 2980, 1615, 1568, 1543, 1411, 1396, 1356, 1327, 1268, 1210, 1167, 1141, 1092, 1016, 964, 88, 847, 821, 715, $667 \mathrm{~cm}^{-1} .{ }^{1} \mathrm{H}-\mathrm{NMR}\left(300 \mathrm{MHz}, \mathrm{CDCl}_{3}\right): \delta=8.15$ $(\mathrm{d}, J=8.4 \mathrm{~Hz}, 4 \mathrm{H}), 7.96(\mathrm{~d}, J=8.4 \mathrm{~Hz}, 4 \mathrm{H}), 1.38(\mathrm{~s}, 24 \mathrm{H}) .{ }^{13} \mathrm{C}-\mathrm{NMR}\left(75 \mathrm{MHz}, \mathrm{CDCl}_{3}\right): \delta=164.9,135.5$, 132.8, 126.2, 122.8, 84.4, 25.0. HRMS (ESI/Q-TOF) $\mathrm{m} / z$ : $[\mathrm{M}+\mathrm{H}]^{+}$calcd for $\mathrm{C}_{26} \mathrm{H}_{33} \mathrm{~B}_{2} \mathrm{~N}_{2} \mathrm{O}_{5}$ 475.2576; found 475.2574. UV (MeOH): $\lambda_{\max }(\varepsilon)=207.5$ (39430), 243.0 (13340), 291.5 (37080).

3.2.6. General Procedure for the Preparation of Unsymmetrical Quinazolinylphenyl-1,3,4-Oxadiazole Derivatives 8a-c, 8f,g via Suzuki Cross-Coupling from Boronic Acid Pinacol Ester $\mathbf{6}$

The appropriate halogen-containing quinazoline derivative (0.31 mmol): 2-(4-bromophenyl)-4( $N, N$-dimethylamino)quinazoline (2a), 2-(3-bromophenyl)-4-( $N, N$-dimethylamino)quinazoline (2b), 2-(2-bromophenyl)-4-( $N, N$-dimethylamino)quinazoline (2c), 6-chloro-4-( $N, N$-dimethylamino)-2- 
phenylquinazoline (2d), 7-chloro-4-( $N, N$-dimethylamino)-2-phenylquinazoline (2e), 6-bromo-4-( $N, N$ dimethylamino)-2-phenylquinazoline (2f), 7-bromo-4-( $N, N$-dimethylamino)-2-phenyl-quinazoline (2g), 2-phenyl-5-[4-(tetramethyl-1,3,2-dioxaborolan-2-yl)phenyl]-1,3,4-oxadiazole (6) (128 mg; $0.37 \mathrm{mmol}$ ), $\mathrm{Na}_{2} \mathrm{CO}_{3}$ (162 mg; $\left.1.53 \mathrm{mmol}\right), \mathrm{Bu}_{4} \mathrm{NBr}(10 \mathrm{mg} ; 0.03 \mathrm{mmol})$ were dissolved in toluene $(3.3 \mathrm{~mL})$ and $\mathrm{H}_{2} \mathrm{O}(1.7 \mathrm{~mL})$ in glass tube reactor, and the mixture was bubbled with Ar followed by addition of $\mathrm{Pd}(\mathrm{dppf}) \mathrm{Cl}_{2}(11 \mathrm{mg} ; 0.015 \mathrm{mmol})$. Glass tube reactor was sealed, and the reaction was stirred at $115^{\circ} \mathrm{C}$ overnight. The solvent was evaporated, and the residue was portioned between DCM and $\mathrm{H}_{2} \mathrm{O}$. The resulting mixture was extracted with DCM twice $(2 \times 10 \mathrm{~mL})$. Product was purified by column chromatography (silica gel, eluent: $0-10 \%$ EtOAc in DCM) followed by trituration with $n$-hexane or EtOAc to yield the appropriate derivatives $\mathbf{8 a}-\mathbf{c}, \mathbf{8 f}-\mathbf{g}$. In the reactions of $\mathbf{2 d}$ and $\mathbf{2 e}$, no conversion was observed.

N,N-Dimethyl-2-(4'-(5-phenyl-1,3,4-oxadiazol-2-yl)biphenyl-4-yl)quinazolin-4-amine (8a). The product was obtained as a beige solid (122 mg, 85\%); $\mathrm{mp} 216{ }^{\circ} \mathrm{C} ; \mathrm{R}_{f}=0.15$ (DCM-EtOAc, 9:1). IR (ATR): 2939, 1610, $1562,1551,1523,1484,1449,1422,1400,1375,1335,1266,1215,1177,1125,1105,1070,1028,1005,973$, 954, 921, 878, 870, 846, 830, 799, 766, 734, 709, 701, $682 \mathrm{~cm}^{-1} .{ }^{1} \mathrm{H}-\mathrm{NMR}\left(300 \mathrm{MHz}, \mathrm{CDCl}_{3}\right) \delta=8.70$ $(\mathrm{d}, J=8.2 \mathrm{~Hz}, 2 \mathrm{H}), 8.25(\mathrm{~d}, J=8.2 \mathrm{~Hz}, 2 \mathrm{H}), 8.22-8.16(\mathrm{~m}, 2 \mathrm{H}), 8.03(\mathrm{dd}, J=23.5,8.2 \mathrm{~Hz}, 2 \mathrm{H}), 7.84$ $(\mathrm{dd}, J=20.0,8.2 \mathrm{~Hz}, 4 \mathrm{H}), 7.74(\mathrm{t}, J=7.8 \mathrm{~Hz}, 1 \mathrm{H}), 7.62-7.53(\mathrm{~m}, 3 \mathrm{H}), 7.41(\mathrm{t}, J=7 . \mathrm{Hz}, 1 \mathrm{H}), 3.49(\mathrm{~s}, 6 \mathrm{H})$. ${ }^{13} \mathrm{C}-\mathrm{NMR}\left(75 \mathrm{MHz}, \mathrm{CDCl}_{3}\right) \delta=164.6,164.5,163.9,158.7,153.0,144.2,141.1,138.8,132.1,131.7,129.1$, 129.0, 128.7, 127.7, 127.4, 127.0, 127.0, 125.6, 124.2, 124.0, 122.8, 115.0, 41.9. HRMS (ESI/Q-TOF) $\mathrm{m} / \mathrm{z}$ : $[\mathrm{M}+\mathrm{H}]^{+}$calcd for $\mathrm{C}_{30} \mathrm{H}_{24} \mathrm{~N}_{5} \mathrm{O} 470.1981$; found 470.1983. UV (MeOH): $\lambda_{\max }(\varepsilon)=201.5(44520), 214.0$ (19760), 316.5 (50600).

N,N-Dimethyl-2-(4'-(5-phenyl-1,3,4-oxadiazol-2-yl)biphenyl-3-yl)quinazolin-4-amine (8b). The product was obtained as a beige solid (106 $\mathrm{mg}, 74 \%$ ); $\mathrm{mp} 177^{\circ} \mathrm{C} ; \mathrm{R}_{f}=0.21$ (DCM-EtOAc, 9:1). IR (ATR): 3060, 2880, 1612, 1564, 1526, 1502, 1485, 1476, 1456, 1413, 1395, 1375, 1359, 1332, 1270, 1231, 1189, 1163, 1100, 1072, 1042, 1026, 1016, 959, 920, 848, 819, 799, 788, 773, 727, 712, 749, 697, $686 \mathrm{~cm}^{-1} .{ }^{1} \mathrm{H}-\mathrm{NMR}(300 \mathrm{MHz}$, $\left.\mathrm{CDCl}_{3}\right) \delta=8.90(\mathrm{t}, J=1.8 \mathrm{~Hz}, 1 \mathrm{H}), 8.63(\mathrm{dt}, J=7.8,1.4 \mathrm{~Hz}, 1 \mathrm{H}), 8.30-8.22(\mathrm{~m}, 2 \mathrm{H}), 8.22-8.14(\mathrm{~m}, 2 \mathrm{H}), 8.06$ $(\mathrm{dd}, J=8.3,1.4 \mathrm{~Hz}, 1 \mathrm{H}), 7.99(\mathrm{dd}, J=8.5,1.4 \mathrm{~Hz}, 1 \mathrm{H}), 7.95-7.88(\mathrm{~m}, 2 \mathrm{H}), 7.80-7.67(\mathrm{~m}, 2 \mathrm{H}), 7.66-7.50$ $(\mathrm{m}, 4 \mathrm{H}), 7.40(\mathrm{ddd}, J=8.3,6.9,1.3 \mathrm{~Hz}, 1 \mathrm{H}), 3.48(\mathrm{~s}, 6 \mathrm{H}) .{ }^{13} \mathrm{C}-\mathrm{NMR}\left(75 \mathrm{MHz}, \mathrm{CDCl}_{3}\right) \delta=164.6,164.6$, 163.9, 158.9, 153.0, 144.7, 139.7, 139.7, 132.1, 131.7, 129.1, 128.9, 128.8, 128.6, 128.3, 127.8, 127.4, 127.1, 127.0, 125.6, 124.2, 124.0, 122.6, 115.0, 41.8. HRMS (ESI/Q-TOF) $\mathrm{m} / \mathrm{z}:[\mathrm{M}+\mathrm{H}]^{+}$calcd for $\mathrm{C}_{30} \mathrm{H}_{24} \mathrm{~N}_{5} \mathrm{O}$ 470.1981; found 470.2014. UV (MeOH): $\lambda_{\max }(\varepsilon)=201.5$ (75350), 217.5 (52110), 304.0 (66480).

N,N-Dimethyl-2-(4'-(5-phenyl-1,3,4-oxadiazol-2-yl)biphenyl-2-yl)quinazolin-4-amine (8c). The product was obtained as a beige solid (123 mg, 86\%); mp $172{ }^{\circ} \mathrm{C} ; \mathrm{R}_{f}=0.10$ (DCM-EtOAc, 9:1). IR (ATR): 3053, 2029, 1613, 1560, 1548, 1520, 1481, 1444, 1411, 1401, 1381, 1345, 1329, 1269, 1219, 1180, 1095, 1075, 1050, 1022, 1006, 955, 920, 838, 760, 740, 734, 707, $682 \mathrm{~cm}^{-1} .{ }^{1} \mathrm{H}-\mathrm{NMR}\left(300 \mathrm{MHz}, \mathrm{CDCl}_{3}\right) \delta=8.18-8.10$ $(\mathrm{m}, 3 \mathrm{H}), 8.05-7.99(\mathrm{~m}, 2 \mathrm{H}), 7.96(\mathrm{dd}, J=8.5,1.3 \mathrm{~Hz}, 1 \mathrm{H}), 7.91(\mathrm{dd}, J=8.5,1.3 \mathrm{~Hz}, 1 \mathrm{H}), 7.71(\mathrm{ddd}$, $J=8.5,6.9,1.4 \mathrm{~Hz}, 1 \mathrm{H}), 7.60-7.48(\mathrm{~m}, 6 \mathrm{H}), 7.45-7.38(\mathrm{~m}, 3 \mathrm{H}), 2.95(\mathrm{~s}, 6 \mathrm{H}) .{ }^{13} \mathrm{C}-\mathrm{NMR}\left(75 \mathrm{MHz}, \mathrm{CDCl}_{3}\right)$ $\delta=164.7,164.5,162.8,161.8,152.7,147.0,140.5,139.3,132.1,131.7,131.0,130.5,129.9,129.1,129.1$, 128.6, 128.2, 126.9, 126.3, 125.5, 124.4, 124.0, 121.5, 114.3, 41.4. HRMS (ESI/Q-TOF) $\mathrm{m} / \mathrm{z}:[\mathrm{M}+\mathrm{H}]^{+}$calcd for $\mathrm{C}_{30} \mathrm{H}_{24} \mathrm{~N}_{5} \mathrm{O}$ 470.1981; found 470.1983. UV $(\mathrm{MeOH}): \lambda_{\max }(\varepsilon)=201.5(59880), 211.0(49960), 243.5$ (30930), 302.5 (43720).

N,N-Dimethyl-2-phenyl-6-(4-(5-phenyl-1,3,4-oxadiazol-2-yl)phenyl)quinazolin-4-amine (8f). The product was obtained as a yellowish solid $(107 \mathrm{mg}, 75 \%) ; \mathrm{mp} 234^{\circ} \mathrm{C} ; \mathrm{R}_{f}=0.24$ (DCM-EtOAc, 9:1). IR (ATR): 3067, 2890, 2169, 1612, 1579, 15512, 1523, 1505, 1486, 1449, 1417, 1396, 1352, 1325, 1243, 1172, 1131, 1104, 1069, 1027, 1015, 959, 891, 852, 829, 803, 790, 776, 743, 733, 713, 692, 684, $673 \mathrm{~cm}^{-1} .{ }^{1} \mathrm{H}-\mathrm{NMR}$ $\left(300 \mathrm{MHz}, \mathrm{CDCl}_{3}\right) \delta=8.61(\mathrm{dd}, J=7.7,2.0 \mathrm{~Hz}, 2 \mathrm{H}), 8.32-8.23(\mathrm{~m}, 3 \mathrm{H}), 8.23-8.15(\mathrm{~m}, 2 \mathrm{H}), 8.11-7.97$ (m, 2H), 7.88-7.78 (m, 2H), 7.63-7.46 (m, 6H), $3.53(\mathrm{~s}, 6 \mathrm{H}) .{ }^{13} \mathrm{C}-\mathrm{NMR}\left(75 \mathrm{MHz}, \mathrm{CDCl}_{3}\right) \delta=164.7,164.4$, $164.1,159.7,152.9,143.8,138.7,135.4,131.8,131.0,130.2$, 129.5, 129.1, 128.4, 128.3, 127.6, 127.6, 127.0, 
124.0, 123.9, 122.9, 115.2, 41.9. HRMS (ESI/Q-TOF) $m / z$ : $[\mathrm{M}+\mathrm{H}]^{+}$calcd for $\mathrm{C}_{30} \mathrm{H}_{24} \mathrm{~N}_{5} \mathrm{O}$ 470.1981; found 470.1986. UV (DCM): $\lambda_{\max }(\varepsilon)=228.5$ (36300), 297.0 (56350), 354.5 (44090).

N,N-Dimethyl-2-phenyl-7-(4-(5-phenyl-1,3,4-oxadiazol-2-yl)phenyl)quinazolin-4-amine (8g). The product was obtained as a colourless solid (104 mg, 72\%); $\mathrm{mp} 238-239{ }^{\circ} \mathrm{C} ; \mathrm{R}_{f}=0.27$ (DCM-EtOAc, 9:1). IR (ATR): 3061, 2862, 1615, 1560, 1533, 1480, 1449, 1428, 1416, 1398, 1381, 1348, 1269, 1235, 1197, 1158, 1141, 1125, 1077, 1064, 1031, 1018, 992, 956, 911, 869, 843, 823, 797, 778, 760, 740, 732, $703 \mathrm{~cm}^{-1} .{ }^{1} \mathrm{H}-\mathrm{NMR}$ $\left(300 \mathrm{MHz}, \mathrm{CDCl}_{3}\right) \delta=8.66-8.56(\mathrm{~m}, 2 \mathrm{H}), 8.31-8.20(\mathrm{~m}, 3 \mathrm{H}), 8.23-8.08(\mathrm{~m}, 3 \mathrm{H}), 7.93(\mathrm{~d}, J=8.0 \mathrm{~Hz}, 2 \mathrm{H})$, $7.66(\mathrm{dd}, J=8.7,2.0 \mathrm{~Hz}, 1 \mathrm{H}), 7.62-7.47(\mathrm{~m}, 6 \mathrm{H}), 3.49(\mathrm{~s}, 6 \mathrm{H}) .{ }^{13} \mathrm{C}-\mathrm{NMR}\left(75 \mathrm{MHz}, \mathrm{CDCl}_{3}\right) \delta=164.7,164.4$, 163.5, 159.9, 153.5, 143.0, 142.9, 138.8, 131.8, 130.1, 129.1, 128.4, 128.3, 127.9, 127.5, 127.0, 126.6, 126.3, $123.9,123.5,122.9,114.4,41.8$. HRMS (ESI/Q-TOF) $m / z:[\mathrm{M}+\mathrm{H}]^{+}$calcd for $\mathrm{C}_{30} \mathrm{H}_{24} \mathrm{~N}_{5} \mathrm{O}$ 470.1981; found 470.1993. UV (DCM): $\lambda_{\max }(\varepsilon)=226.5$ (33990), 267.5 (42800), 314.0 (74470).

3.2.7. General Procedure for Preparing Symmetrical Quinazolinylphenyl-1,3,4-oxadiazole Derivatives 9a-c, 9f,g via Suzuki Cross-Coupling Using Diboronic Acid bis(pinacol) Ester 7

The appropriate halogen-containing quinazoline derivative ( $0.50 \mathrm{mmol})$ : 2-(4-bromophenyl)4( $N, N$-dimethylamino)quinazoline (2a), 2-(3-bromophenyl)-4-( $N, N$-dimethylamino)quinazoline (2b), 2-(2-bromophenyl)-4-( $N, N$-dimethylamino)quinazoline (2c), 6-bromo-4-( $N, N$-dimethylamino)-2phenylquinazoline (2f), 7-bromo-4-( $N, N$-dimethylamino)-2-phenylquinazoline (2g), and bis[4-(tetramethyl1,3,2-dioxaborolan-2-yl) phenyl] -1,3,4-oxadiazole (7) (125 mg; $0.28 \mathrm{mmol}), \mathrm{Na}_{2} \mathrm{CO}_{3}$ (224 mg; $2.11 \mathrm{mmol}$ ), $\mathrm{Bu}_{4} \mathrm{NBr}(14 \mathrm{mg} ; 0.042 \mathrm{mmol})$ were dissolved in toluene $(6.6 \mathrm{~mL})$ and $\mathrm{H}_{2} \mathrm{O}(3.4 \mathrm{~mL})$ in glass tube reactor and the mixture was bubbled with Ar followed by addition of $\mathrm{Pd}(\mathrm{dppf}) \mathrm{Cl}_{2}(15 \mathrm{mg} ; 0.021 \mathrm{mmol})$. The glass tube reactor was sealed, and the reaction was stirred at $115^{\circ} \mathrm{C}$ overnight. The solvent was evaporated, and the residue was portioned between DCM and $\mathrm{H}_{2} \mathrm{O}$. The resulting mixture was extracted with DCM twice $(2 \times 10 \mathrm{~mL})$. The final product was purified by column chromatography (silica gel, eluent: 0-10\% EtOAc in DCM, 1-5\% MeOH in DCM), followed by trituration with EtOAc to yield the appropriate symmetrical derivatives $\mathbf{9 a - c}$ and $\mathbf{9 e - f}$.

2,2'-(4',4' -(1,3,4-Oxadiazole-2,5-diyl)bis(biphenyl-4',4-diyl))bis(N,N-dimethylquinazolin-4-amine) (9a). The product was obtained as a pale yellow solid (106 mg, 70\%); mp $271^{\circ} \mathrm{C}$ (decomp.); $\mathrm{R}_{f}=0.47(5 \% \mathrm{MeOH}$ in DCM). IR (ATR): 2933, 1610, 1560, 1522, 1485, 1448, 1395, 1375, 1352, 1335, 1271, 1214, 1176, 1102, 1070, 1020, 1005, 954, 924, 866, 834, 798, 763, 739, 701, $680 \mathrm{~cm}^{-1} .{ }^{1} \mathrm{H}-\mathrm{NMR}\left(300 \mathrm{MHz}, \mathrm{CDCl}_{3}\right) \delta=8.70$ $(\mathrm{d}, J=8.2 \mathrm{~Hz}, 4 \mathrm{H}), 8.27(\mathrm{~d}, J=8.4 \mathrm{~Hz}, 4 \mathrm{H}), 8.06(\mathrm{~d}, J=8.5 \mathrm{~Hz}, 2 \mathrm{H}), 7.98(\mathrm{~d}, J=8.2 \mathrm{~Hz}, 2 \mathrm{H}), 7.88(\mathrm{~d}$, $J=8.5 \mathrm{~Hz}, 4 \mathrm{H}), 7.80(\mathrm{~d}, J=8.4 \mathrm{~Hz}, 4 \mathrm{H}), 7.73(\mathrm{t}, J=7.3 \mathrm{~Hz}, 2 \mathrm{H}), 7.40(\mathrm{t}, J=7.7 \mathrm{~Hz}, 2 \mathrm{H}), 3.49(\mathrm{~s}, 12 \mathrm{H}) .{ }^{13} \mathrm{C}$ $\operatorname{NMR}\left(75 \mathrm{MHz}, \mathrm{CDCl}_{3}\right) \delta=164.7,164.0,158.9,153.1,144.3,141.2,138.9,132.2,129.2,128.8,127.5,127.1$, 127.1, 125.7, 124.4, 122.9, 115.1, 42.0. HRMS (ESI/Q-TOF) $m / z:[\mathrm{M}+\mathrm{H}]^{+}$calcd for $\mathrm{C}_{46} \mathrm{H}_{37} \mathrm{~N}_{8} \mathrm{O}$ 717.3090; found 717.3060. UV (MeOH): $\lambda_{\max }(\varepsilon)=212.0$ (12290), 269.0 (5150), 331.0 (12890).

2,2'-(4', ,4'-(1,3,4-Oxadiazole-2,5-diyl)bis(biphenyl-4',3-diyl))bis(N,N-dimethylquinazolin-4-amine) (9b). The product was obtained as a cream solid $(76 \mathrm{mg}, 50 \%)$; m 265-266 ${ }^{\circ} \mathrm{C} ; \mathrm{R}_{f}=0.48$ (5\% MeOH in DCM). IR (ATR): 3059, 2927, 1612, 1564, 1526, 1488, 1446, 1411, 1399, 1378, 13356, 1232, 1162, 1102, 1069, 1041, $1015,961,917,888,866,845,807,791,761,752,729,709,695,680 \mathrm{~cm}^{-1} .{ }^{1} \mathrm{H}-\mathrm{NMR}\left(300 \mathrm{MHz}, \mathrm{CDCl}_{3}\right)$ $\delta=8.90(\mathrm{t}, J=1.8 \mathrm{~Hz}, 2 \mathrm{H}), 8.62(\mathrm{dt}, J=7.8,1.2 \mathrm{~Hz}, 2 \mathrm{H}), 8.28(\mathrm{~d}, J=8.4 \mathrm{~Hz}, 4 \mathrm{H}), 8.06(\mathrm{dd}, J=8.5,1.3 \mathrm{~Hz}$, $2 \mathrm{H}), 7.98(\mathrm{dd}, J=8.5,1.2 \mathrm{~Hz}, 2 \mathrm{H}), 7.92(\mathrm{~d}, J=8.4 \mathrm{~Hz}, 4 \mathrm{H}), 7.74(\mathrm{tdd}, J=8.4,6.6,1.5 \mathrm{~Hz}, 4 \mathrm{H}), 7.61(\mathrm{t}$, $J=7.7 \mathrm{~Hz}, 2 \mathrm{H}), 7.40(\mathrm{ddd}, J=8.4,6.6,1.3 \mathrm{~Hz}, 2 \mathrm{H}), 3.48(\mathrm{~s}, 12 \mathrm{H}) .{ }^{13} \mathrm{C}-\mathrm{NMR}\left(75 \mathrm{MHz}, \mathrm{CDCl}_{3}\right) \delta=164.6$, 164.0, 158.9, 153.0, 144.7, 139.8, 139.7, 132.1, 128.9, 128.8, 128.7, 128.3, 127.9, 127.4, 127.2, 125.6, 124.2, 122.7, 115.0, 41.9. HRMS (ESI/Q-TOF) $m / z$ : $[\mathrm{M}+\mathrm{H}]^{+}$calcd for $\mathrm{C}_{46} \mathrm{H}_{37} \mathrm{~N}_{8} \mathrm{O}$ 717.3090; found 717.3065. UV (MeOH): $\lambda_{\max }(\varepsilon)=206.5$ (10690), 210.5 (11190), 252.5 (9230), 267.5 (8940), 316.5 (11120).

2,2'-(4', ,4'-(1,3,4-Oxadiazole-2,5-diyl)bis(biphenyl-4',2-diyl))bis(N,N-dimethylquinazolin-4-amine) (9c). The product was obtained as a colourless solid $(91 \mathrm{mg}, 60 \%) ; \mathrm{mp} 165-166{ }^{\circ} \mathrm{C} ; \mathrm{R}_{f}=0.43(5 \% \mathrm{MeOH}$ in DCM). IR (ATR): 2927, 1732, 1611, 1562, 1522, 1499, 1444, 1398, 1375, 1351, 1240, 1219, 1142, 1095, 1071, 
$1047,1021,1005,955,879,86,807,765,739,708,638 \mathrm{~cm}^{-1} .{ }^{1} \mathrm{H}-\mathrm{NMR}\left(300 \mathrm{MHz}, \mathrm{CDCl}_{3}\right) \delta=8.14-8.09$ $(\mathrm{m}, 2 \mathrm{H}), 8.00-7.84(\mathrm{~m}, 8 \mathrm{H}), 7.69(\mathrm{ddd}, J=8.4,6.9,1.4 \mathrm{~Hz}, 2 \mathrm{H}), 7.57-7.44(\mathrm{~m}, 6 \mathrm{H}), 7.42-7.33(\mathrm{~m}, 6 \mathrm{H})$, 2.94 (s, 12H). ${ }^{13} \mathrm{C}-\mathrm{NMR}\left(75 \mathrm{MHz}, \mathrm{CDCl}_{3}\right) \delta=164.6,162.8,161.8,152.7,147.0,140.4,139.3,132.1,130.9$, $130.5,129.8,129.1,128.6,128.2,126.3,125.5,124.4,121.5,114.3,41.4$. HRMS (ESI/Q-TOF) $m / z:[M+H]^{+}$ calcd for $\mathrm{C}_{46} \mathrm{H}_{37} \mathrm{~N}_{8} \mathrm{O}$ 717.3090; found 717.3065. UV (MeOH): $\lambda_{\max }(\varepsilon)=207.5$ (10490), 249.0 (54350), 314.5 (61870).

6,6'-(4,4'-(1,3,4-Oxadiazole-2,5-diyl)bis(4,1-phenylene))bis(N,N-dimethylquinazolin-4-amine)(9f). The product was obtained as a yellow solid(79 $\mathrm{mg}, 52 \%) ; \mathrm{mp} 378-330{ }^{\circ} \mathrm{C} ; \mathrm{R}_{f}=0.70(5 \% \mathrm{MeOH}$ in DCM). IR (ATR): 3058, 2881, 2170, 1608, 1584, 1553, 1520, 1485, 1449, 1413, 1390, 1348, 1324, 1240, 1191, 1168, 1105, 1066, $1026,1013,958,891,829,803,779,749,708,672 \mathrm{~cm}^{-1} .{ }^{1} \mathrm{H}-\mathrm{NMR}\left(300 \mathrm{MHz}, \mathrm{CDCl}_{3}\right) \delta=8.66-8.57(\mathrm{~m}, 4 \mathrm{H})$, 8.37-8.27 (m, 6H), 8.16-8.00 (m, 4H), $7.88(\mathrm{~d}, J=8.2 \mathrm{~Hz}, 4 \mathrm{H}), 7.52(\mathrm{~d}, J=7.0 \mathrm{~Hz}, 6 \mathrm{H}), 3.55(\mathrm{~s}, 12 \mathrm{H})$. ${ }^{13} \mathrm{C}-\mathrm{NMR}\left(75 \mathrm{MHz}, \mathrm{CDCl}_{3}\right) \delta=164.8,160.3,159.8,153.0,143.9,138.8,135.5,131.2,130.3,129.6,129.3$, 128.6, 128.4, 127.1, 124.1, 123.0, 115.3, 42.08. HRMS (ESI/Q-TOF) $m / z:[\mathrm{M}+\mathrm{H}]^{+}$calcd for $\mathrm{C}_{46} \mathrm{H}_{37} \mathrm{~N}_{8} \mathrm{O}$ 717.3090; found 717.3088. UV (DCM): $\lambda_{\max }(\varepsilon)=228.5$ (55720), 292.0 (50750), 361.0 (80530).

7,7'-(4,4'-(1,3,4-Oxadiazole-2,5-diyl)bis(4,1-phenylene))bis(N,N-dimethylquinazolin-4-amine)(9g). The product was obtained as a beige solid(98 mg, 65\%); $\mathrm{mp} 257-258{ }^{\circ} \mathrm{C}$ (decomp.); $\mathrm{R}_{f}=0.45$ (5\% MeOH in DCM). IR (ATR): 2881, 1614, 1559, 1533, 1474, 1453, 1429, 1382, 1345, 1201, 1167, 1103, 1068, 1026, 1014, 955, $911,890,847,823,798,777,746,704 \mathrm{~cm}^{-1} .{ }^{1} \mathrm{H}-\mathrm{NMR}\left(300 \mathrm{MHz}, \mathrm{CDCl}_{3}\right) \delta=8.67-8.57(\mathrm{~m}, 4 \mathrm{H}), 8.36-8.23$ $(\mathrm{m}, 6 \mathrm{H}), 8.16(\mathrm{~d}, J=8.7 \mathrm{~Hz}, 2 \mathrm{H}), 7.96(\mathrm{~d}, J=8.1 \mathrm{~Hz}, 4 \mathrm{H}), 7.70(\mathrm{dd}, J=8.7,1.9 \mathrm{~Hz}, 2 \mathrm{H}), 7.59-7.46(\mathrm{~m}, 6 \mathrm{H})$, 3.52 (s, 12H). ${ }^{13} \mathrm{C}-\mathrm{NMR}\left(75 \mathrm{MHz}, \mathrm{CDCl}_{3}\right) \delta=164.5,163.6,159.9,153.5,143.1,143.0,138.7,130.2,128.4$, $128.3,128.0,127.6,126.7,126.4,123.5,122.9,114.4,41.8$. HRMS (ESI/Q-TOF) $m / z:[\mathrm{M}+\mathrm{H}]^{+}$calcd for $\mathrm{C}_{46} \mathrm{H}_{37} \mathrm{~N}_{8} \mathrm{O}$ 717.3090; found 717.3096. UV (DCM): $\lambda_{\max }(\varepsilon)=222.0$ (37810), 276.0 (50200), 329.0 (110400).

\section{Conclusions}

In conclusion, we have synthesized two series of novel, highly-conjugated, unsymmetrical and symmetrical quinazolinylphenyl-1,3,4-oxadiazole compounds. We demonstrated a simple and efficient synthetic methodology that involves Suzuki cross-coupling reactions between bromine-containing 4-(N,N-dimethylamine)-2-phenylquinazoline derivatives and 2,5-diphenyl-1,3,4-oxadiazole-bearing boronic esters in the presence of a palladium catalyst under phase transfer catalytic conditions. The prepared boronic acid pinacol ester and diboronic acid bis(pinacol) ester of 2,5-diphenyl-1,3,4-oxadiazole were effective precursors for the described Suzuki cross-coupling reactions. Both the boronic esters 6 , $\mathbf{7}$ and final products $\mathbf{8 f}, \mathbf{9 f}$, wherein the 1,3,4-oxadiazole moiety is connected to quinazoline ring by a 1,4-phenylene linker at the 6 position, displayed strong fluorescence emission and high quantum yields, making these compounds potentially useful building blocks for optoelectronic applications.

Supplementary Materials: Copies of the ${ }^{1} \mathrm{H}-\mathrm{NMR}$ and ${ }^{13} \mathrm{C}-\mathrm{NMR}$ spectra of the compounds are available in the online Supplementary Materials.

Author Contributions: B.W. and A.K. conceived and designed the experiments, performed the experiments and analyzed the data. M.W. and M.K. performed absorption and emission measurements. A.K. and B.W. wrote the manuscript. All authors have read and agreed to the published version of the manuscript.

Funding: This research was funded by the Silesian University of Technology in Gliwice, Poland, grant number 04/050/BK_20/0097.

Acknowledgments: The authors would like to thank Department of Organic Chemistry, Jagiellonian University (Kraków, Poland) for the opportunity to register fluorescence spectra.

Conflicts of Interest: The authors declare no conflict of interest. 


\section{References}

1. Zhou, Y.; Wang, J.; Gu, Z.; Wang, S.; Zhu, W.; Aceña, J.L.; Soloshonok, V.A.; Izawa, K.; Liu, H. Next Generation of Fluorine-Containing Pharmaceuticals, Compounds Currently in Phase II-III Clinical Trials of Major Pharmaceutical Companies: New Structural Trends and Therapeutic Areas. Chem. Rev. 2016, 116, 422-518. [CrossRef]

2. Summa, V.; Petrocchi, A.; Bonelli, F.; Crescenzi, B.; Donghi, M.; Ferrara, M.; Fiore, F.; Gardelli, C.; Gonzalez Paz, O.; Hazuda, D.J.; et al. Discovery of Raltegravir, a Potent, Selective Orally Bioavailable HIV-Integrase Inhibitor for the Treatment of HIV-AIDS Infection. Med. Chem. 2008, 51, 5843-5855. [CrossRef]

3. Tan, T.M.C.; Chen, Y.; Kong, K.H.; Bai, J.; Li, Y.; Lim, S.G.; Ang, T.H.; Lam, Y. Synthesis and the biological evaluation of 2-benzenesulfonylalkyl-5-substituted-sulfanyl-[1,3,4]-oxadiazoles as potential anti-hepatitis B virus agents. Antivir. Res. 2006, 71,7-14. [CrossRef]

4. De Oliveira, C.S.; Lira, B.F.; Barbosa-Filho, J.M.; Lorenzo, J.G.F.; De Athayde-Filho, P.F. Synthetic Approaches and Pharmacological Activity of 1,3,4-Oxadiazoles: A Review of the Literature from 2000-2012. Molecules 2012, 17, 10192-10231. [CrossRef]

5. Rachakonda, V.; Alla, M.; Kotipalli, S.S.; Ummanni, R. Design, diversity-oriented synthesis and structure activity relationship studies of quinolinyl heterocycles as antimycobacterial agents. Eur. J. Med. Chem. 2013, 70, 536-547. [CrossRef] [PubMed]

6. Zhang, M.-Z.; Mulholland, N.; Beattie, D.; Irwin, D.; Gu, Y.-C.; Chen, Q.; Yang, G.-F.; Clough, J. Synthesis and antifungal activity of 3-(1,3,4-oxadiazol-5-yl)-indoles and 3-(1,3,4-oxadiazol-5-yl)methyl-indoles. Eur. J. Med. Chem. 2013, 63, 22-32. [CrossRef]

7. Reddy, G.D.; Park, S.J.; Cho, H.M.; Kim, T.J.; Lee, M.E. Antiallergic activity profile in vitro RBL-2H3 and in vivo passive cutaneous anaphylaxis mouse model of new sila-substituted 1,3,4-oxadiazoles. J. Med. Chem. 2012, 55, 6438-6444. [CrossRef]

8. Paun, A.; Hadade, N.D.; Paraschivescu, C.C.; Matache, M. 1,3,4-Oxadiazoles as luminescent materials for organic light emitting diodes via cross-coupling reactions. J. Mater. Chem. C 2016, 4, 8596-8610. [CrossRef]

9. Yang, X.; Xu, X.; Zhou, G. Recent advances of the emitters for high performance deep-blue organic light-emitting diodes. J. Mater. Chem. C 2015, 3, 913-944. [CrossRef]

10. Han, J. 1,3,4-Oxadiazole based liquid crystals. J. Mater. Chem. C 2013, 1, 7779-7797. [CrossRef]

11. Zheng, C.; Yuan, A.; Zhang, Z.; Shen, H.; Bai, S.; Wang, H. Synthesis of pyridine-based 1,3,4-oxadiazole derivative as fluorescence turn-on sensor for high selectivity of Ag+. J. Fluoresc. 2013, 23, 785-791. [CrossRef]

12. Tang, L.; Zheng, Z.; Huang, Z.; Zhong, K.; Bian, Y.; Nandhakumar, R. Multi-analyte, ratiometric and relay recognition of a 2,5-diphenyl-1,3,4-oxadiazole-based fluorescent sensor through modulating ESIPT. RSC Adv. 2015, 5, 10505-10511. [CrossRef]

13. Dong, Y.-B.; Zhang, Q.; Wang, L.; Ma, J.-P.; Huang, R.-Q.; Shen, D.-Z.; Chen, D.-Z. Organometallic Coordination Polymers Generated from Bent Bis(acetylenylphenyl)oxadiazole Ligands and Ag(I) Salts. Inorg. Chem. 2005, 44, 6591-6608. [CrossRef]

14. Theocharis, A.B.; Alexandrou, N.E. Synthesis and spectral data of 4,5-bis[5-aryl-1,3,4-oxadiazol-2-yl]-1-benzyl1,2,3-triazoles. J. Heterocycl. Chem. 1990, 27, 1685-1688. [CrossRef]

15. Tandon, V.K.; Chhor, R.B. An efficient one pot synthesis of 1,3,4-oxadiazoles. Synth. Commun. 2001, 31, 1727-1732. [CrossRef]

16. Stabile, P.; Lamonica, A.; Ribecai, A.; Castoldi, D.; Guercio, G.; Curcuruto, O. Mild and convenient one-pot synthesis of 1,3,4-oxadiazoles. Tetrahedron Lett. 2010, 51, 4801-4805. [CrossRef]

17. Dobrota, C.; Paraschivescu, C.; Dumitru, I.; Matache, M.; Baciu, I.; Ruta, L.L. Convenient preparation of unsymmetrical 2,5-disubstituted 1,3,4-oxadiazoles promoted by Dess-Martin reagent. Tetrahedron Lett. 2009, 50, 1886-1888. [CrossRef]

18. Pardeshi, S.P.; Patil, S.S.; Bobade, V.D. N-Chlorosuccinimide/1,8-Diazabicyclo[5.4.0]undec-7-ene (DBU)-Mediated Synthesis of 2,5-Disubstituted 1,3,4-Oxadiazoles. Synth. Commun. 2010, 40, 1601-1606. [CrossRef]

19. Rapolu, S.; Alla, M.; Bommenaa, V.R.; Murthy, R.; Jain, N.; Bommareddy, V.R.; Bommineni, M.R. Synthesis and biological screening of 5-(alkyl(1H-indol-3-yl))-2-(substituted)-1,3,4-oxadiazoles as antiproliferative and anti-inflammatory agents. Eur. J. Med. Chem. 2013, 66, 91-100. [CrossRef] 
20. Rostamizadeh, S.; Housaini, S.A.G. Microwave assisted syntheses of 2,5-disubstituted 1,3,4-oxadiazoles. Tetrahedron Lett. 2004, 45, 8753-8756. [CrossRef]

21. Jasiak, K.; Kudelko, A.; Zieliński, W.; Kuźnik, N. Study on DDQ-promoted synthesis of 2,5-disubstituted 1,3,4-oxadiazoles from acid hydrazides and aldehydes. ARKIVOC 2017, 2, 87-106. [CrossRef]

22. Buscemi, S.; Pace, A.; Pibiri, I.; Vivona, N. Competing Ring-Photoisomerization Pathways in the 1,2,4-Oxadiazole Series. An Unprecedented Ring-Degenerate Photoisomerization. J. Org. Chem. 2002, 67, 6253-6255. [CrossRef]

23. Shaker, R.M.; Mahmoud, A.F.; Abdel-Latif, F.F. Synthesis and Biological Activities of Novel 1,4-Bridged Bis-1,2,4-Triazoles, Bis-1,3,4-Thiadiazoles and Bis-1,3,4-Oxadiazoles. Phosphorus Sulfur Silicon Relat. Elements 2005, 180, 397-406. [CrossRef]

24. Xie, Y.; Liu, J.; Yang, P.; Shi, X.; Li, J. Synthesis of 2-amino-1,3,4-oxadiazoles from isoselenocyanates via cyclodeselenization. Tetrahedron 2011, 67, 5369-5374. [CrossRef]

25. Dupau, P.; Epple, R.; Thomas, A.A.; Fokin, V.V.; Sharpless, K.B. Osmium-Catalyzed Dihydroxylation of Olefins in Acidic Media: Old Process, New Tricks. Adv. Synth. Catal. 2002, 344, 421-433. [CrossRef]

26. Huisgen, R.; Sauer, J.; Sturm, H.J.; Markgraf, J.H. Ring opening of azoles. II. The formation of 1,3,4-oxadiazoles in the acylation of 5-substituted tetrazoles. Chem. Ber. 1960, 93, 2106-2124. [CrossRef]

27. Verhaeghe, P.; Azas, N.; Gasquet, M.; Hutter, S.; Ducros, C.; Laget, M.; Rault, S.; Rathelot, P.; Vanelle, P. Synthesis and antiplasmodial activity of new 4-aryl-2-trichloromethylquinazolines. Bioorg. Med. Chem. Lett. 2008, 18, 396-401. [CrossRef]

28. Chandrika, P.M.; Yakaiah, T.; Rao, A.R.R.; Narsaiah, B.; Reddy, N.C.; Sridhar, V.; Rao, J.V. Synthesis of novel 4,6-disubstituted quinazoline derivatives, their anti-inflammatory and anti-cancer activity (cytotoxic) against U937 leukemia cell lines. Eur. J. Med. Chem. 2008, 43, 846-852. [CrossRef] [PubMed]

29. Giardin, D.; Martarelli, D.; Sagratini, G.; Angeli, P.; Ballinari, D.; Gulini, U.; Melchiorre, C.; Poggesi, E.; Pompei, P. Doxazosin-Related $\alpha 1$-Adrenoceptor Antagonists With Prostate Antitumor Activity. J. Med. Chem. 2009, 52, 4951-4954. [CrossRef]

30. Shallal, H.M.; Russu, W.A. Discovery, synthesis, and investigation of the antitumor activity of novel piperazinylpyrimidine derivatives. Eur. J. Med. Chem. 2011, 46, 2043-2057. [CrossRef]

31. El-Azab, A.S.; Abdel-Hamide, S.G.; Sayed-Ahmed, M.M.; Hassan, G.S.; El-Hadiyah, T.M.; Al-Shabanah, O.A.; Al-Deeb, O.A.; El-Subbagh, H.I. Novel 4(3H)-Quinazolinone Analogues: Synthesis and Anticonvulsant Activity. Med. Chem. Res. 2013, 22, 2815-2827. [CrossRef]

32. Elshahawi, M.M.; El-Ziaty, A.K.; Morsy, J.M.; Aly, A.F. Synthesis and Insecticidal Efficacy of Novel Bis Quinazolinone Derivatives. J. Heterocycl. Chem. 2015, 53, 1443-1448. [CrossRef]

33. Bowen Li, B.; Wang, Z.; Su, S.-J.; Guo, F.; Cao, Y.; Zhang, Y. Quinazoline-Based Thermally Activated Delayed Fluorecence for High-Performance OLEDs with External Quantum Efficiencies Exceeding 20\%. Adv. Opt. Mater. 2019, 1801496. [CrossRef]

34. Jiang, J.B.; Hesson, D.P.; Dusak, B.A.; Dexter, D.L.; Kang, G.L.; Hamel, E. Synthesis and biological evaluation of 2-styrylquinazolin-4(3H)-ones, a new class of antimitotic anticancer agents which inhibit tubulin polymerization. J. Med. Chem. 1990, 33, 1721-1728. [CrossRef] [PubMed]

35. Rad-Moghadam, K.; Mohseni, M. An Expeditious and Solvent-Free Route to the Synthesis of 2-Substituted Quinazolin-4(3H)-Ones Under Microwave Conditions. J. Chem. Res. 2003, 8, 487-488. [CrossRef]

36. Bergman, J.; Brynolf, A. Synthesis of Chrysogine, a Metabolite of Penicillium chrysogenum and some related 2-substituted 4-(3H)-Quinazolinones. Tetrahedron Lett. 1990, 46, 1295-1310. [CrossRef]

37. Witt, A.; Bergman, J. Synthesis and Reactions of some 2-Vinyl-3H-quinazolin-4-ones. Tetrahedron 2000, 56, 7245-7253. [CrossRef]

38. Connolly, D.J.; Guiry, P.J. A Facile and Versatile Route to 2-Substituted-4(3H)-Quinazolinones and Quinazolines. Synlett 2001, 11, 1707-1710. [CrossRef]

39. Hess, H.-J.; Cronin, T.H.; Scriabine, A. Antihypertensive 2-amino-4(3H)-quinazolinones. J. Med. Chem. 1968, 11, 130-136. [CrossRef]

40. Connolly, D.J.; Cusack, D.; O'Sullivan, T.P.; Guiry, P.J. Synthesis of quinazolinones and quinazolines. Tetrahedron 2005, 61, 10153-10202. [CrossRef]

41. Asif, M. Chemical Characteristics, Synthetic Methods, and Biological Potential of Quinazoline and Quinazolinone Derivatives. Int. J. Med. Chem. 2014, 2014, 395637. [CrossRef]

42. Zhang, J.; Zhu, D.; Yu, C.; Wan, C.; Wang, Z. A Simple and Efficient Approach to the Synthesis of 2-Phenylquinazolines via $\mathrm{sp}^{3} \mathrm{C}-\mathrm{H}$ Functionalization. Org. Lett. 2010, 12, 2841-2843. [CrossRef] 
43. Karnakar, K.; Shangkar, J.; Murthy, S.N.; Ramesch, K.; Nageshwar, Y.V.D. An Efficient Protocol for the Synthesis of 2-Phenylquinazolines Catalyzed by Ceric Ammonium Nitrate (CAN). Synlett 2011, 8, 1089-1096. [CrossRef]

44. Kraft, A.; Grimsdale, A.C.; Holmes, A.B. Electroluminescent Conjugated Polymers-Seeing Polymers in a New Light. Angew. Chem. Int. Ed. 1998, 37, 402-428. [CrossRef]

45. Mitschke, U.; Bauerle, P. The electroluminescence of organic materials. J. Mater. Chem. 2000, 10, $1471-1507$. [CrossRef]

46. Wang, C.; Jung, G.-Y.; Hua, Y.; Pearson, C.; Bryce, M.R.; Petty, M.C.; Batsanov, A.S.; Goeta, A.E.; Howard, J.A.K. An Efficient Pyridine- and Oxadiazole-Containing Hole-Blocking Material for Organic Light-Emitting Diodes: Synthesis, Crystal Structure, and Device Performance. Chem. Mater. 2001, 13, 1167-1173. [CrossRef]

47. Wang, C.; Jung, G.-Y.; Batsanov, A.S.; Bryce, M.R.; Petty, M.C. New electron-transporting materials for light emitting diodes: 1,3,4-oxadiazole-pyridine and 1,3,4-oxadiazole-pyrimidine hybrids. J. Mater. Chem. 2002, 12, 173-180. [CrossRef]

48. Waśkiewicz, K.; Gabański, R.; Żak, J.; Suwiński, J. Electrochemical Isomerization and Polymerization of Three Stereoisomers of a Novel Photoluminescent Thienylene-PPV Derivative. Electrochem. Solid-State Lett. 2005, 8, E24-E26. [CrossRef]

49. Fuks-Janczarek, I.; Reshak, A.H.; Kuźnik, N.; Kityk, I.V.; Gabański, R.; Łapkowski, M.; Motyka, R.; Suwiński, J. UV-vis absorption spectra of 1,4-dialkoxy-2,5-bis[2-(thien-2-yl)ethenyl]benzenes. Spectrochim. Acta Part A 2009, 72, 394-398. [CrossRef]

50. Tamoto, N.; Adachi, C.; Nagai, K. Electroluminescence of 1,3,4-Oxadiazole and Triphenylamine-Containing Molecules as an Emitter in Organic Multilayer Light Emitting Diodes. Chem. Mater. 1997, 9, 1077-1085. [CrossRef]

51. Kudelko, A.; Wróblowska, M.; Jarosz, T.; Łaba, K.; Łapkowski, M. Synthesis, spectral characteristics and electrochemistry of symmetrically substituted hybrids derived from 2,5-bis(4-bromophenyl)-1,3,4-oxadiazole under Suzuki cross-coupling reaction. ARKIVOC 2015, 5, 287-302. [CrossRef]

52. Wróblowska, M.; Kudelko, A.; Łapkowski, M. Efficient Synthesis of Conjugated 1,3,4-Thiadiazole Hybrids through Palladium-Catalyzed Cross-Coupling of 2,5-Bis(4-bromophenyl)-1,3,4-thiadiazole with Boronic Acids. Synlett 2015, 26, 2127-2130. [CrossRef]

53. Olesiejuk, M.; Kudelko, A.; Świątkowski, M.; Kruszyński, R. Synthesis of 4-alkyl-4H-1,2,4-triazole derivatives by Suzuki cross-coupling reactions and their luminescence properties. Molecules 2019, 24, 652. [CrossRef]

54. Suzuki, A. Cross-coupling reactions via organoboranes. J. Organomet. Chem. 2002, 653, 83-90. [CrossRef]

55. Miyaura, N. Metal-Catalyzed Cross-Coupling Reactions of Organoboron Compounds with Organic Halides. In Metal-Catalyzed Cross-Coupling Reactions; de Meijere, A., Diederich, F., Eds.; Wiley-VCH: Weinheim, Germany, 2008; pp. 41-123.

56. Zieliński, W.; Kudelko, A.; Holt, E.M. Synthesis of 2,4-Diaminoquinazoline Derivatives. Heterocycles 1998, 48, 319-328. [CrossRef]

57. Zieliński, W.; Kudelko, A. The synthesis of 8-hydroxyquinazoline derivatives and their acid-base interactions. J. Heterocycl. Chem. 2004, 41, 247-251. [CrossRef]

58. Zieliński, W.; Kudelko, A. Synthesis and Basicity of 4-Amino-2-phenylquinazolines. Monatshefte Chem. 2000, 131, 895-899. [CrossRef]

59. Jose, D.E.; Kanchana, U.S.; Mathew, T.V.; Anilkumar, G. Recent studies in Suzuki-Miyaura cross-coupling reactions with the aid of phase transfer catalysts. J. Organomet. Chem. 2020, 927, 121538. [CrossRef]

60. Castanet, A.-S.; Colobert, F.; Desmurs, J.-R.; Schlama, T. Biaryl synthesis via Suzuki coupling promoted by catalytic amounts of quaternary ammonium salts. J. Mol. Catal. A Chem. 2002, 182-183, 481-487. [CrossRef]

61. Polackova, V.; Hut'ka, M.; Toma, S. Ultrasound effect on Suzuki reactions. 1. Synthesis of unsymmetrical biaryls. Ultrason. Sonochem. 2005, 12, 99-102. [CrossRef]

62. Badone, D.; Baroni, M.; Cardamone, R.; Ielmini, A.; Guzzi, U. Highly Efficient Palladium-Catalyzed Boronic Acid Coupling Reactions in Water: Scope and Limitations. J. Org. Chem. 1997, 62, 7170-7173. [CrossRef] [PubMed]

63. Suzuki. K.; Kobayashi, A.; Kaneko, S.; Takehira, K.; Yoshihara, T.; Ishida, H.; Shiina, Y.; Oishi, S.; Tobita, S. Reevaluation of absolute luminescence quantum yields of standard solutions using a spectrometer with an integrating sphere and a back-thinned CCD detector. Phys. Chem. Chem. Phys. 2009, 11, 9850-9860. [CrossRef] 
64. Dahl, K.; Biswas, R.; Maroncelli, M. The Photophysics and Dynamics of Diphenylbutadiene in Alkane and Perfluoroalkane Solvents. J. Phys. Chem. B 2003, 107, 7838-7853. [CrossRef]

65. Brouwer, A.M. Standards for photoluminescence quantum yield measurements in solution (IUPAC Technical Report). Pure Appl. Chem. 2011, 83, 2213-2228. [CrossRef]

66. Lakowicz, J.R. Quenching of Fluorescence. In Principles of Fluorescence Spectroscopy, 3rd ed.; Springer: Boston, MA, USA, 2006; Chapter 8; pp. 277-330. [CrossRef]

67. Chen, X.; Yang, Q.; Zhou, Y.; Deng, Z.; Mao, X.; Peng, Y. Synthesis of 4-(Dimethylamino)quinazoline via Direct Amination of Quinazolin-4(3H)-one Using N,N-Dimethylformamide as a Nitrogen Source at Room Temperature. Synthesis 2015, 47, 2055-2062. [CrossRef]

68. Zieliński, W.; Mazik, M. Synthesis of 4-aminoquinazoline derivatives. Pol. J. Chem. 1994, 68, 487-489.

69. Kawano, T.; Yoshizumi, T.; Hirano, K.; Satoh, T.; Miura, M. Copper-Mediated Direct Arylation of 1,3,4-Oxadiazoles and 1,2,4-Triazoles with Aryl Iodides. Org. Lett. 2009, 11, 3072-3075. [CrossRef]

70. Zhan, X.; Liu, Y.; Wu, X.; Wang, S.; Zhu, D. New Series of Blue-Emitting and Electron-Transporting Copolymers Based on Fluorene. Macromolecules 2002, 35, 2529-2537. [CrossRef]

Sample Availability: Samples of the compounds 8a-c, 8f,g, 9a-c, 9f,g are available from the authors

Publisher's Note: MDPI stays neutral with regard to jurisdictional claims in published maps and institutional affiliations.

(C) 2020 by the authors. Licensee MDPI, Basel, Switzerland. This article is an open access article distributed under the terms and conditions of the Creative Commons Attribution (CC BY) license (http://creativecommons.org/licenses/by/4.0/). 